University of South Florida

DIGITAL COMMONS

Digital Commons @ University of

@ UNIVERSITY OF SOUTH FLORIDA

South Florida

3-8-2006

\title{
Reproducibility of Geochemical and Climatic Signals in the
} Atlantic Coral Montastraea Faveolata

\author{
Jennifer M. Smith \\ University of South Florida \\ Terrence M. Quinn \\ University of South Florida, quinn@marine.usf.edu \\ Kevin P. Helmle \\ National Coral Reef Institute \\ Robert B. Halley \\ U.S. Geological Survey
}

Follow this and additional works at: https://digitalcommons.usf.edu/msc_facpub

Part of the Marine Biology Commons

\section{Scholar Commons Citation \\ Smith, Jennifer M.; Quinn, Terrence M.; Helmle, Kevin P.; and Halley, Robert B., "Reproducibility of Geochemical and Climatic Signals in the Atlantic Coral Montastraea Faveolata" (2006). Marine Science Faculty Publications. 114. \\ https://digitalcommons.usf.edu/msc_facpub/114}

This Article is brought to you for free and open access by the College of Marine Science at Digital Commons @ University of South Florida. It has been accepted for inclusion in Marine Science Faculty Publications by an authorized administrator of Digital Commons @ University of South Florida. For more information, please contact digitalcommons@usf.edu. 


\title{
Reproducibility of geochemical and climatic signals in the Atlantic coral Montastraea faveolata
}

\author{
Jennifer M. Smith, ${ }^{1}$ Terrence M. Quinn, ${ }^{1}$ Kevin P. Helmle, ${ }^{2}$ and Robert B. Halley ${ }^{3}$ \\ Received 27 June 2005; revised 2 November 2005; accepted 16 November 2005; published 8 March 2006.
}

[1] Monthly resolved, 41-year-long stable isotopic and elemental ratio time series were generated from two separate heads of Montastraea faveolata from Looe Key, Florida, to assess the fidelity of using geochemical variations in Montastraea, the dominant reef-building coral of the Atlantic, to reconstruct sea surface environmental conditions at this site. The stable isotope time series of the two corals replicate well; mean values of $\delta^{18} \mathrm{O}$ and $\delta^{13} \mathrm{C}$ are indistinguishable between cores (compare $0.70 \%$ versus $0.68 \%$ for $\delta^{13} \mathrm{C}$ and $-3.90 \%$ o versus $-3.94 \%$ for $\delta^{18} \mathrm{O}$ ). Mean values from the $\mathrm{Sr} / \mathrm{Ca}$ time series differ by $0.037 \mathrm{mmol} / \mathrm{mol}$, which is outside of analytical error and indicates that nonenvironmental factors are influencing the coral $\mathrm{Sr} / \mathrm{Ca}$ records at Looe Key. We have generated significant $\delta^{18} \mathrm{O}$-sea surface temperature $(\mathrm{SST})(\mathrm{R}=-0.84)$ and $\mathrm{Sr} / \mathrm{Ca}-\mathrm{SST}(\mathrm{R}=$ -0.86) calibration equations at Looe Key; however, these equations are different from previously published equations for Montastraea. Variations in growth parameters or kinetic effects are not sufficient to explain either the observed differences in the mean offset between $\mathrm{Sr} / \mathrm{Ca}$ time series or the disagreement between previous calibrations and our calculated $\delta^{18} \mathrm{O}-\mathrm{SST}$ and $\mathrm{Sr} / \mathrm{Ca}-\mathrm{SST}$ relationships. Calibration differences are most likely due to variations in seawater chemistry in the continentally influenced waters at Looe Key. Additional geochemical replication studies of Montastraea are needed and should include multiple coral heads from open ocean localities complemented whenever possible by seawater chemistry determinations.

Citation: Smith, J. M., T. M. Quinn, K. P. Helmle, and R. B. Halley (2006), Reproducibility of geochemical and climatic signals in the Atlantic coral Montastraea faveolata, Paleoceanography, 21, PA1010, doi:10.1029/2005PA001187.

\section{Introduction}

[2] Measurements of sea surface temperature (SST) and sea surface salinity (SSS) in the tropical oceans are spatially and temporally limited, which hinders understanding of tropical ocean-atmosphere dynamics on subcentennial timescales. Increasing our understanding of tropical climate prior to the instrumental period requires the use of proxy indicators of tropical surface ocean variability. The geochemistry of coral skeletons is one such climate proxy, which also has the added benefit of having subannual resolution. Stable isotope $\left(\delta^{18} \mathrm{O}, \delta^{13} \mathrm{C}\right)$ and elemental ratio variations $(\mathrm{Sr} / \mathrm{Ca}, \mathrm{Mg} / \mathrm{Ca})$ are the most widely used coralbased climate proxies.

[3] The $\delta^{18} \mathrm{O}$ of the coral skeleton varies in response to changes in both temperature and seawater $\delta^{18} \mathrm{O}_{\mathrm{w}}\left(\delta_{\mathrm{w}}\right)$. The $\delta_{\mathrm{w}}$, in turn, has been shown to vary linearly with patterns of salinity although the slope of that relationship varies as a function of location [Fairbanks et al., 1992]. Coral skeletal $\delta^{18} \mathrm{O}$ records alone have proven an effective tool in tracking SST [e.g., Fairbanks and Dodge, 1979], $\delta_{\mathrm{w}}$ [e.g., Cole et

\footnotetext{
${ }^{1}$ College of Marine Science, University of South Florida, St. Petersburg, Florida, USA.

${ }^{2}$ Nova Southeastern University Oceanographic Center, National Coral Reef Institute, Dania Beach, Florida, USA.

${ }^{3}$ U.S. Geological Survey, St. Petersburg, Florida, USA.

Copyright 2006 by the American Geophysical Union. 0883-8305/06/2005PA001187
}

al., 1993; Linsley et al., 1994; Le Bec et al., 2000], and combined variations in SST and $\delta_{\mathrm{w}}$ [Gagan et al., 2000].

[4] Coral $\mathrm{Sr} / \mathrm{Ca}$ thermometry has been increasingly used as an independent means to estimate SST. Some workers have used paired measurements of coral $\mathrm{Sr} / \mathrm{Ca}$ and $\delta^{18} \mathrm{O}$ to estimate $\delta_{\mathrm{w}}$, and thus salinity over a variety of time periods [McCulloch et al., 1994; Gagan et al., 1998; Cardinal et al., 2001; Correge et al., 2004; Kilbourne et al., 2004]. Sr/Ca ratios of biogenic aragonite are controlled by both a temperature-dependent distribution coefficient and the $\mathrm{Sr} /$ Ca ratio of the fluid from which it is precipitated $\left(\mathrm{Sr} / \mathrm{Ca}_{\mathrm{w}}\right)$ [Kinsman and Holland, 1969; Smith et al., 1979]. As a result of the long residence times of strontium and calcium in the global ocean $\left(6\right.$ and $0.7 \times 10^{6}$ years, respectively, for $\mathrm{Sr}$ and $\mathrm{Ca}$ [Pilson, 1998]), seawater is often assumed to have an invariant $\mathrm{Sr} / \mathrm{Ca}_{\mathrm{w}}$ ratio over the time periods of most coral-based climate reconstructions. Recent work by several investigators has questioned this assumption. de Villiers et al. [1994] found small variations in $\mathrm{Sr} / \mathrm{Ca}_{\mathrm{w}}$ in the Galapagos Islands associated with upwelled waters from depth. These $\mathrm{Sr} / \mathrm{Ca}_{\mathrm{w}}$ variations translate into temperature variations $\leq 0.2^{\circ} \mathrm{C}$. Direct measurements of Pacific $\mathrm{Sr} / \mathrm{Ca}_{\mathrm{w}}$ indicate a difference of $\sim 0.03 \mathrm{mmol} / \mathrm{mol}\left(\sim 0.5^{\circ} \mathrm{C}\right)$ between water at the surface and $\sim 100 \mathrm{~m}$ [de Villiers et al., 1994; Alibert et al., 2003]. Time series measurements of $\mathrm{Sr} / \mathrm{Ca}_{\mathrm{w}}$ taken from the shallow waters of southern Taiwan indicate a range of $0.033 \mathrm{mmol} / \mathrm{mol}$ over the course of one year [Shen et al., 1996]. More recent data from the Indian Ocean adjacent to Western Australia show large variations in surface $\mathrm{Sr} / \mathrm{Ca}$ values ranging from 8.6 to $9.2 \mathrm{mmol} / \mathrm{mol}$ [de Deckker, 
2004]. Seawater $\mathrm{Sr}$ concentrations also respond to the sequestering of $\mathrm{Sr}$ in the celestite $\left(\mathrm{SrSO}_{4}\right)$ skeleton of acantharian populations [Bernstein et al., 1992]. These marine pelagic protists are globally distributed in surface oligotrophic waters and may also impact $\mathrm{Sr} / \mathrm{Ca}$ values measured in corals [Brass, 1980; de Deckker, 2004]. Indeed, recent studies have suggested that seawater $\mathrm{Sr}$ variations greatly exceed those of seawater $\mathrm{Ca}$ variations, and this variation is thought to be a major factor responsible for disparities in $\mathrm{Sr} / \mathrm{Ca}$ thermometers in Porites [Sun et al., 2005]. Thus, despite the long ocean residence times of $\mathrm{Sr}$ and $\mathrm{Ca}$, several studies have begun to address the potential impact of both the spatial and temporal variability of $\mathrm{Sr} / \mathrm{Ca}$ in open and coastal oceans.

[5] Coral $\mathrm{Sr} / \mathrm{Ca}$ may also be influenced by variations in coral growth, specifically extension and calcification rates. de Villiers et al. [1994] concluded that slower (faster) extension rates were associated with higher (lower) Pavona $\mathrm{Sr} / \mathrm{Ca}$ ratios creating an offset between two different sampling transects on the same coral with different extension rates (6 versus $12 \mathrm{~mm} / \mathrm{yr}$ ). However, other studies have shown no relationship between Porites $\mathrm{Sr} / \mathrm{Ca}$ and skeletal extension rate over a much larger range of extension rates $(8-24 \mathrm{~mm} / \mathrm{yr})$ [Shen et al., 1996; Alibert and McCulloch, 1997; Gagan et al., 1998]. Moreover, Alibert and McCulloch [1997] demonstrated that coral $\mathrm{Sr} / \mathrm{Ca}$ is also independent of calcification rate by showing the similarity of $\mathrm{Sr} / \mathrm{Ca}$ time series in two separate specimens with contrasting growth parameters. Alibert and McCulloch [1997] also emphasized the importance of sampling the major growth axis as opposed to a marginal region between adjacent fans of corallites to minimize any growth-related effect on $\mathrm{Sr} / \mathrm{Ca}$. There have been few studies on $\mathrm{Sr} / \mathrm{Ca}$ variations in Montastraea, but in one such study Swart et al. [2002] indicated an impact on coral $\mathrm{Sr} / \mathrm{Ca}$ by both sampling density and the difficulties of sampling a complex skeleton; however, they concluded that there is a robust and highly significant relationship between $\mathrm{Sr} / \mathrm{Ca}$ and SST in Montastraea.

[6] Coral-based climate reconstructions of climate variability in the Atlantic in general, and in the Caribbean specifically, have lagged behind that of the Pacific and Indian Oceans largely because of the community's focus on interannual to centennial-scale climate variability in the other tropical ocean basins. Montastraea has proven to be a very utilitarian coral and previous workers have used these corals to develop records of ocean circulation [Druffel, 1983; Druffel and Suess, 1983], upwelling [Reuer et al., 2003; Guilderson et al., 2005], and temperature and insolation [Fairbanks and Dodge, 1979; Gischler and Oschmann, 2005]. Also, application of a paired geochemical approach $\left(\mathrm{Mg} / \mathrm{Ca}, \delta^{18} \mathrm{O}\right)$ has been employed over short time windows to assess changes in temperature and salinity in the Caribbean during the Little Ice Age [Watanabe et al., $2001 \mathrm{~b}$ ]. In spite of previous work, a better understanding of continuous interannual to centennial-scale climate variability in the tropical Atlantic is needed, and it is logical that the dominant reef-building coral of the Atlantic, Montastraea, will play a significant role in any coral-based climate reconstruction of this region.
[7] Previous studies have investigated geochemical reproducibility in Porites over decadal timescales [Guilderson and Schrag, 1999; Linsley et al., 1999; Stephans et al., 2004], whereas in Montastraea it has only been addressed over a period of a few years [Leder et al., 1996; Swart et al., 1996c; Watanabe et al., 2002]. The next logical and necessary step is to assess the reproducibility of geochemical signals of climate variability in Montastraea on decadal timescales. In this study we use geochemical time series generated from two $M$. faveolata coral heads drilled at Looe Key, Florida, to assess how well these two records replicate, and we evaluate whether the geochemical variations in these records reflect environmental variability at this site.

\section{Methods}

\subsection{Setting}

[8] Looe Key, Florida (Figure 1), is a part of the Florida Keys National Marine Sanctuary and is located in the central portion of the Florida Keys $\left(24^{\circ} 33.4^{\prime} \mathrm{N}\right.$, $\left.81^{\circ} 24.75^{\prime} \mathrm{W}\right)$. Bihourly measurements of SST were made at Looe Key Reef from 1990 to 1995 and from 1997 to 1999 (H. Hudson, unpublished data, 1999). These highly resolved, but short, in situ SST time series were augmented with $1^{\circ} \times 1^{\circ}$ gridded SST data from the HadISST1 database [Rayner et al., 2003] extracted at $24^{\circ} \mathrm{N}, 81^{\circ} \mathrm{W}$. In situ data were resampled to monthly resolution and compared with the gridded data, which revealed that the gridded SST product sometimes underestimates winter SST by up to $2{ }^{\circ} \mathrm{C}$ (Figure $2 \mathrm{a}$ ). We created a composite SST time series by adjusting the gridded data set based upon its linear relationship with in situ SST (Figure 2b) from 1961 to 2002, excluding the 7 years of in situ SST. Mean annual SST for $1961-2002$ is $26.6^{\circ} \mathrm{C}\left( \pm 0.2^{\circ} \mathrm{C}, \sigma_{\bar{x}}\right)$. Average maximum SST values $\left(30.0^{\circ} \mathrm{C}\right)$ occur in August and average minimum SST values $\left(23.1^{\circ} \mathrm{C}\right)$ occur in February. These monthly SST extremes (summer SST-winter SST) produce an average annual cycle of $6.9^{\circ} \mathrm{C}$ at Looe Key. As an additional check on our augmentation of the gridded data set, we compare our temperature time series with independent measurements of temperature collected as part of the SERC-FIU Water Quality Monitoring Network taken near quarterly at the reef site from 1995 to 2003 (Figure 2b) and find that the two data sets agree well.

[9] Precipitation patterns over south Florida resemble those typical of subtropical systems with the largest amount of rainfall received in the warm summer months (JulySeptember) and the least in the winter. Determinations of salinity are also available directly from Looe Key reef on a near quarterly basis collected at the same time as the independent temperature measurements. Data from this site indicate a range of salinity $>2$ psu from 1995 to 2003 (Figure 2c). A more complete, although spatially averaged ( $175 \mathrm{~nm}^{2}$, centered on Looe Key), time series over the same time interval indicates a general in-phase relationship between SSS and SST with maximum values in salinity coinciding with maximum SST; however, the phasing of SSS and SST is somewhat variable with a few seasons (i.e., summer 1998 and winter 2001) completely out of phase. Low-salinity events were recorded in March 1996, August 


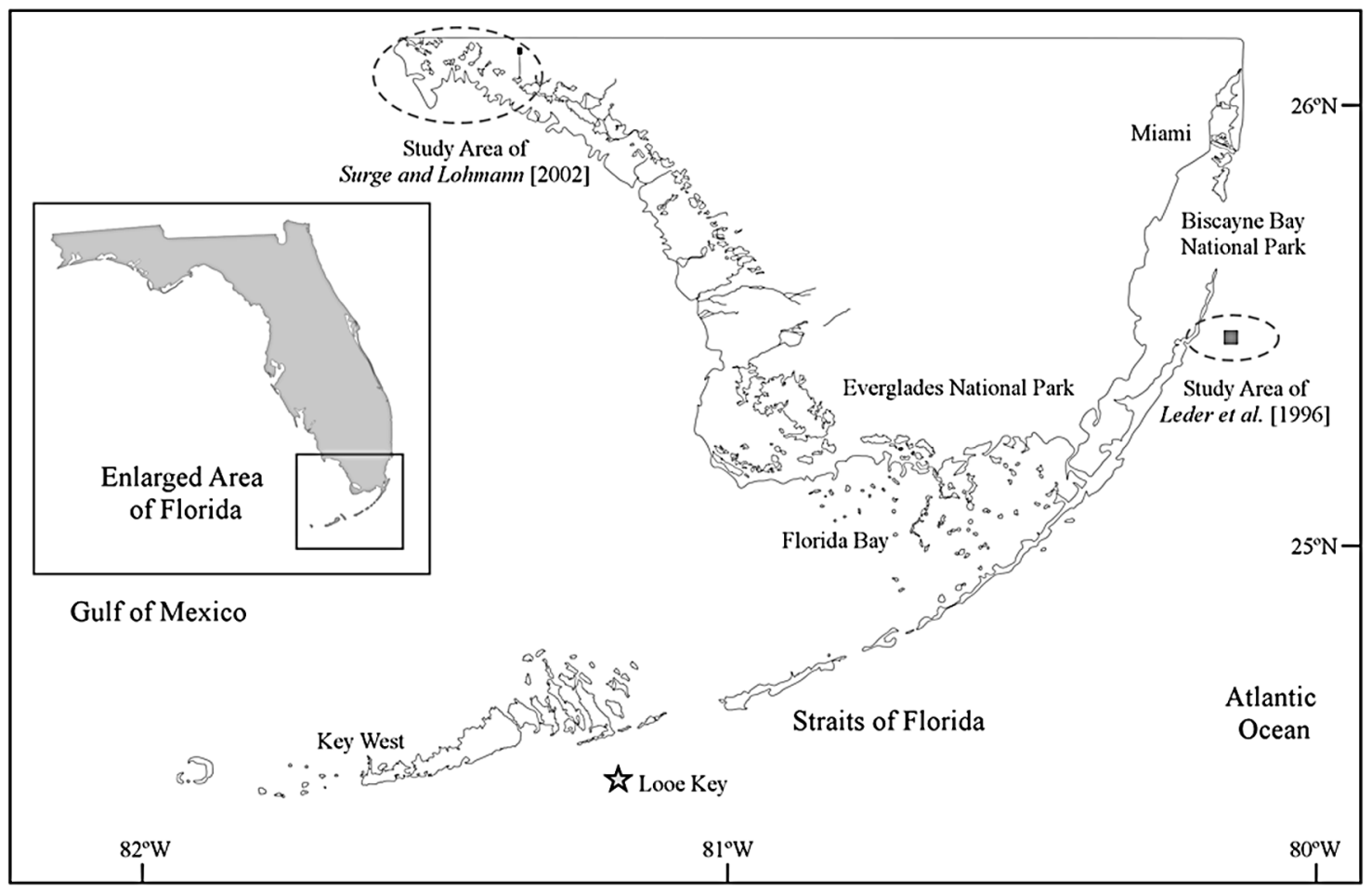

Figure 1. Location map of Looe Key, Florida, United States. Looe Key resides on the seaward (south) side of the Florida Keys and within the Florida Keys National Marine Sanctuary. The study areas of both Surge and Lohmann [2002] and Leder et al. [1996] are marked by dashed circles.

1998, and December 1999. In each of these months, precipitation in southern Florida was below normal, suggesting the freshwater source is continental rather than coming from direct precipitation at the site. The three highest salinity measurements in the record (June 1997, May 1999, and June 2001) all occur in the spring when latent heat flux and evaporation rates are the highest [Virmani and Weisberg, 2003]. Despite the short record length, there appears to be an annual component to SSS variability in addition to variation independent of the annual cycle of SST.

\subsection{Coral Sampling}

[10] Two cores of Montastraea faveolata (LK1, LK23) were collected in August 2002 in $4 \mathrm{~m}$ of water at the seaward side of Looe Key reef from within a $300 \mathrm{~m}$ radius of each other. Montastraea faveolata has been previously termed Montastraea annularis, but recently has been separated into three sibling species [Knowlton et al., 1992] with $M$. faveolata being described as the large massive form that is usually utilized for paleoclimate work. Both LK1 and LK23 cores are $3 \mathrm{~cm}$ in diameter and 40 and $31.5 \mathrm{~cm}$ long, respectively. Each core was slabbed into three portions: two outer pieces and a center flat slab with a thickness of $\sim 5 \mathrm{~mm}$. X-radiographs were made from each flat slab and show clear annual banding (Figure 3). Microsampling for geochemical analysis was performed using a computercontrolled triaxial drill. The center flat portion of LK1 was unavailable for geochemical and additional densitometry analysis; therefore we performed microsampling of LK1 along the inward facing (flat) outer portion of the core. The top portion of LK1 chipped off during initial sampling so a parallel segment $(\sim 1.5$ years) was drilled and the data from this segment were spliced into the time series. Powder from each sample was collected along the major axis of growth on the exothecal wall at $0.5 \mathrm{~mm}$ increments using a $1 \mathrm{~mm}$ diameter drill bit which penetrated each slab to a depth of $1 \mathrm{~mm}$. This sampling yields an average sampling rate of $\sim 14$ samples/year. Horizontally sampled portions of the slab were performed in the same manner with a $0.5 \mathrm{~mm}$ forward step. High-resolution data from LK23 (40 samples/ year) were likewise collected with a $0.5 \mathrm{~mm}$ diameter drill bit with a reduced forward movement of the drill $(\sim 0.2 \mathrm{~mm}$ step). A more detailed discussion of sampling effects is found in section 4.2.1.

\subsection{Densitometry}

[11] Coral slab LK23 was X-radiographed for densitometry after geochemical samples were collected. Coral slabs and wedges were placed on Kodak Industrex AA440 Ready-pack film and exposed at $70 \mathrm{KvP}$ and $15 \mathrm{ma}$ for $7.0 \mathrm{~s}$ with a source to object distance (SOD) of $1 \mathrm{~m}$. A sheet of aluminum was X-radiographed at the same settings to remove influences of the inverse square law and heel effects. Films were developed manually based on manufacturer's specifications. Film negatives were digitized using a medical film single-line scanner.

[12] Relative optic density of the X-radiograph was calibrated to skeletal bulk density of the coral slab using the CoralXDS+program (see K. P. Helmle et al., CoralXDS-The 


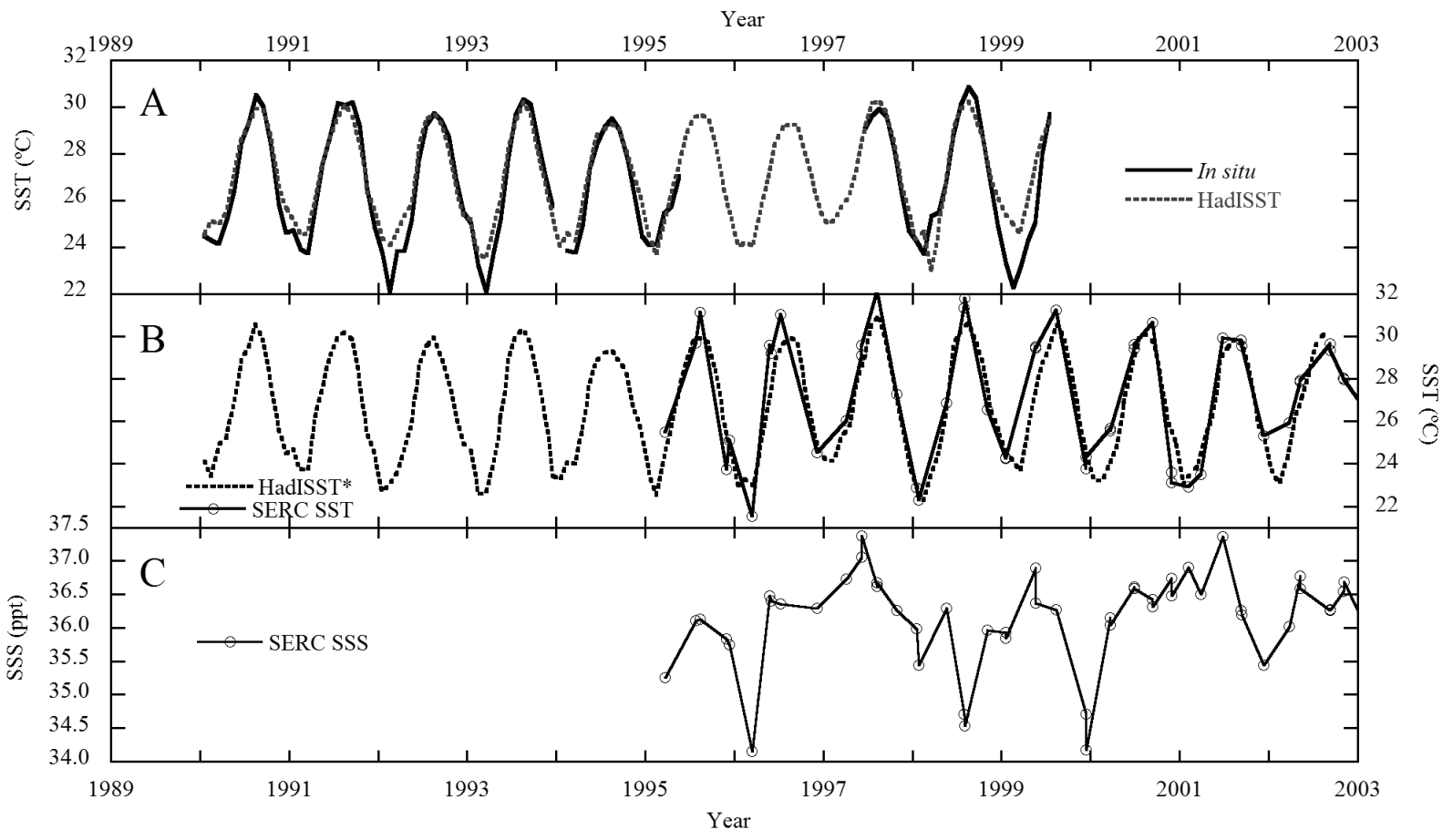

Figure 2. (a) Time series comparison of in situ (solid) and gridded (dashed) sea surface temperature (SST) data (HadISST1.1 [Rayner et al., 2003]) over their common period of overlap. Summer maximum temperatures are well matched in the records; however, the gridded SST product tends to underestimate the SST minima. Discrepancies in the winter SST can be as large as $2^{\circ} \mathrm{C}$. The equation relating these two variables (HadISST $=0.83$ (in situ) $+4.95, \mathrm{R}=0.98$ and $\mathrm{N}=103$ ) was used to adjust the gridded SST time series, which extends back to 1870 , to create an augmented SST record (HadISST*) that more accurately reflects local, reef site SST. (b) Comparison between temperatures derived from the augmented in situ gridded data set (HadISST*, dashed line) and independent daily measurements taken approximately quarterly at Looe Key reef (solid line, open circles). (c) Spatially averaged $\left(\sim 175 \mathrm{~nm}^{2}\right)$ approximately quarterly salinity measurements taken about Looe Key reef from 1995 to 2004.

Coral X-radiograph Densitometry System, Nova Southeastern University, National Coral Reef Institute, posted 4 September 2002, available at http://www.nova.edu/ ocean/coralxds/index.html). Densitometry transects were collected adjacent to, but not overlapping, the drilling trough already present on the slab. Annual bands were delimited based on the zero point of the second derivative (inflection point) between density maxima and minima from a smoothed cubic spline curve of the density data. Density data $\left(\mathrm{g} / \mathrm{cm}^{3}\right)$ were averaged for annual periods using the inflection points of each high-density band as the delimiter. Annual linear extension data $(\mathrm{cm})$ were the distances from the inflection points at the end (top) of each high-density band. Calcification data $\left(\mathrm{g} / \mathrm{cm}^{2}\right)$ were calculated as the product of annual linear extension and annual density data.

[13] Direct densitometry measurements of LK1 were unobtainable because the microdrilled portion of the core had been embedded with epoxy to a metal frame; however, an X-radiograph taken of the original center slab was digitized and used for gray scale luminance measurements $(0-255)$ which provides accurate linear extension data, but cannot be used for collecting density or calcification data because of the lack of a known wedge standard and background X-radiograph.

\subsection{Geochemical Analysis}

[14] The $\delta^{13} \mathrm{C}$ and $\delta^{18} \mathrm{O}$ analyses were performed by reacting $\sim 30-80 \mu \mathrm{g}$ of coral powder with phosphoric acid at $70^{\circ} \mathrm{C}$ in a Kiel III autosampling device connected to a ThermoFinnigan Delta PlusXL mass spectrometer. Replicate analyses of NBS-19 $(n=274)$ run alongside the coral samples indicate an instrumental precision of $0.02 \%$ and $0.06 \%$ for $\delta^{13} \mathrm{C}$ and $\delta^{18} \mathrm{O}$, respectively. All values are reported in standard delta notation relative to the VPDB isotopic standard using the conventional notation.

[15] Elemental analyses of $\mathrm{Sr} / \mathrm{Ca}$ and $\mathrm{Mg} / \mathrm{Ca}$ were performed using a Perkin-Elmer 4300 DV ICP-OES. Sample preparation involved diluting $\sim 75-300 \mu \mathrm{g}$ of coral powder in variable volumes of $2 \%$ trace metal grade $\mathrm{HNO}_{3}$ to achieve a target solution concentration of $\sim 20 \mathrm{ppm} \mathrm{Ca}$. Internal gravimetric references were run between every sample to correct for machine drift following the methods of Schrag [1999]. Precision of our internal gravimetric standard $(1 \sigma)$ was $0.009 \mathrm{mmol} / \mathrm{mol}$ for $\mathrm{Sr} / \mathrm{Ca}$ and $0.013 \mathrm{mmol} / \mathrm{mol}$ for $\mathrm{Mg} / \mathrm{Ca}(\mathrm{n}=256)$. The accuracy of this standard's $\mathrm{Sr} / \mathrm{Ca}$ value has been externally verified by mass spectrometric analysis at the University of Minnesota Isotope Laboratory. As an additional measure of precision, homogenized powder of Porites lutea was included in each 


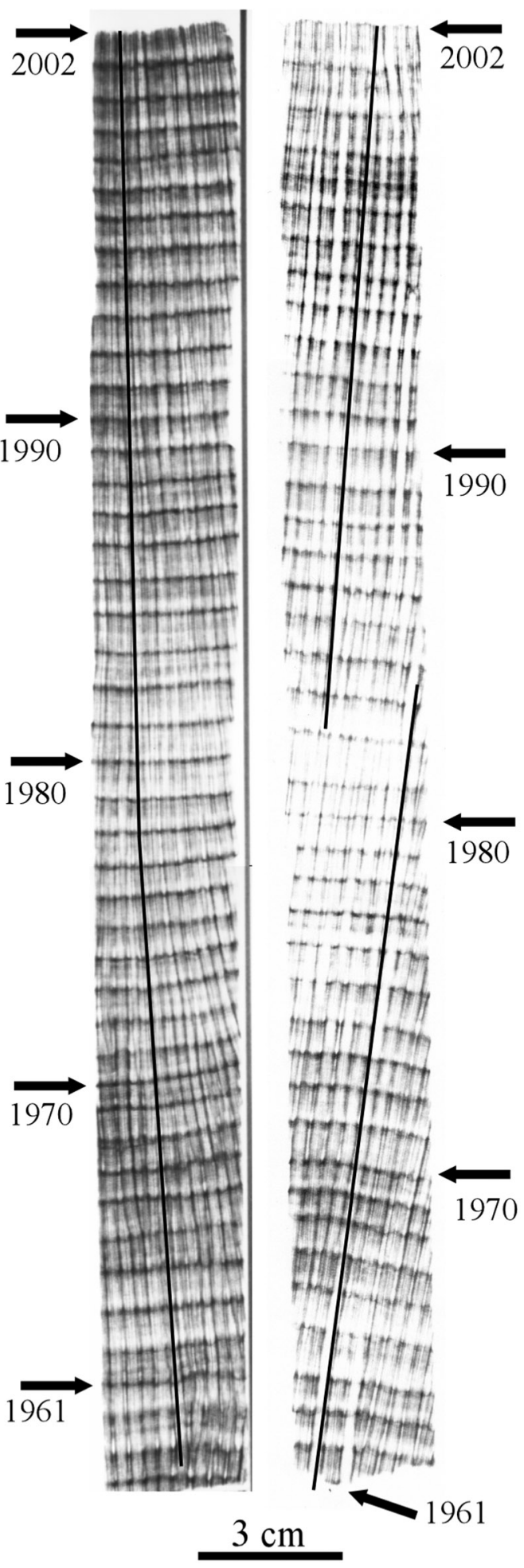

Figure 3. Positive X-radiograph images of slabs from coral cores (left) LK1 and (right) LK23. Distinct density banding is evident in both slabs and is in a nearperpendicular orientation with respect to the axis of the core. Select years are noted in each slab for comparison. Drill paths for each core are indicated by solid vertical lines on each coral slab. run. These values indicate a precision $(1 \sigma)$ of $0.016 \mathrm{mmol} /$ $\mathrm{mol}$ for $\mathrm{Sr} / \mathrm{Ca}$ and $0.044 \mathrm{mmol} / \mathrm{mol}$ for $\mathrm{Mg} / \mathrm{Ca}(\mathrm{n}=363)$.

\subsection{Data Analysis}

[16] Geochemical variations versus depth were translated to a time axis by pairing maximum (minimum) $\mathrm{Sr} / \mathrm{Ca}$ values with minimum (maximum) SST using the Analyseries software [Paillard et al., 1996]. The resultant time series were interpolated to monthly values for comparison with the instrumental SST time series. This age model was verified at an annual scale by comparison with the timing of the annual density-banding pattern. Despite good time-depth control at an annual scale, subannual timing cannot be verified by use of densitometry methods. We estimate an average time assignment error at any one point within a particular year to be $\sim 2$ months. No evidence was present to indicate any type of physical or chemical hiatus over the length of both cores.

[17] Correlation values are reported as Pearson Product Moment correlation coefficients and are significant at the 95\% confidence interval or greater. Climatology calculations are commensurate with the time period of coral growth, 1961-2002. Statistical significance of the calculation of means (i.e., error estimates) is a function of the number of degrees of freedom which is dependent upon the number of independent observations. Given the serial order correlation that exists in a time series because of the annual cycle, the calculated number of degrees of freedom was determined by use of a runs test [see Davis, 2002].

\section{Results}

\subsection{Coral Skeletal Geochemistry}

[18] Well-defined annual cycles are characteristic of the $\delta^{13} \mathrm{C}, \delta^{18} \mathrm{O}$, and $\mathrm{Sr} / \mathrm{Ca}$ time series (Figure 4 and Table 1). The $\mathrm{Mg} / \mathrm{Ca}$ time series (not shown) exhibits an irregular pattern which is presumably due to either the varying presence of organic material and inorganic detritus [Watanabe et al., 2001a] or small contributions of brucite $\left(\mathrm{Mg}\left(\mathrm{OH}_{2}\right)\right)$ [Buster and Holmes, 2006] and will not be discussed.

[19] The climatology of the $\delta^{13} \mathrm{C}$ record indicates peak values occur every year in June or August (LK1 and LK23, respectively) with the most negative values occurring in December. Mean $\delta^{13} \mathrm{C}$ values are $0.70 \% \pm 0.06\left(\sigma_{\bar{x}}\right)$ and $0.68 \% \pm 0.05\left(\sigma_{\bar{x}}\right)$ for LK1 and LK23. The overall difference in mean values between LK1 and LK23 over the 41 years of record is the same as analytical error $(0.02 \%$, Figure 4$)$ and is small when compared with the results of previous studies $(0.82 \%$ [Watanabe et al., 2002] and $0.17 \%$ [Swart et al., 1996c]). However, when taken as the absolute value of differences between each monthly value in the two time series, the average difference becomes $0.46 \%$. The difference drops to $0.24 \%$ after removing variability occurring at less than 2 years. A significant longterm trend toward more negative $\delta^{13} \mathrm{C}$ values is present in both time series and is $-0.02 \% 0 /$ year.

[20] Mean $\delta^{18} \mathrm{O}$ values of LK1 and LK23 during 19612002 differ by $0.04 \%$ (LK1, $-3.90 \%$ o $\pm 0.02\left(\sigma_{\overline{-}}\right)$; LK23, $\left.-3.94 \%=0.03\left(\sigma_{\bar{r}}\right)\right)$ and are not significantly different ( $t$ test, $\mathrm{p}>0.99)$. There is a $0.21 \pm 0.01 \%$ o $\left(\sigma_{\bar{x}}\right)$ difference in 


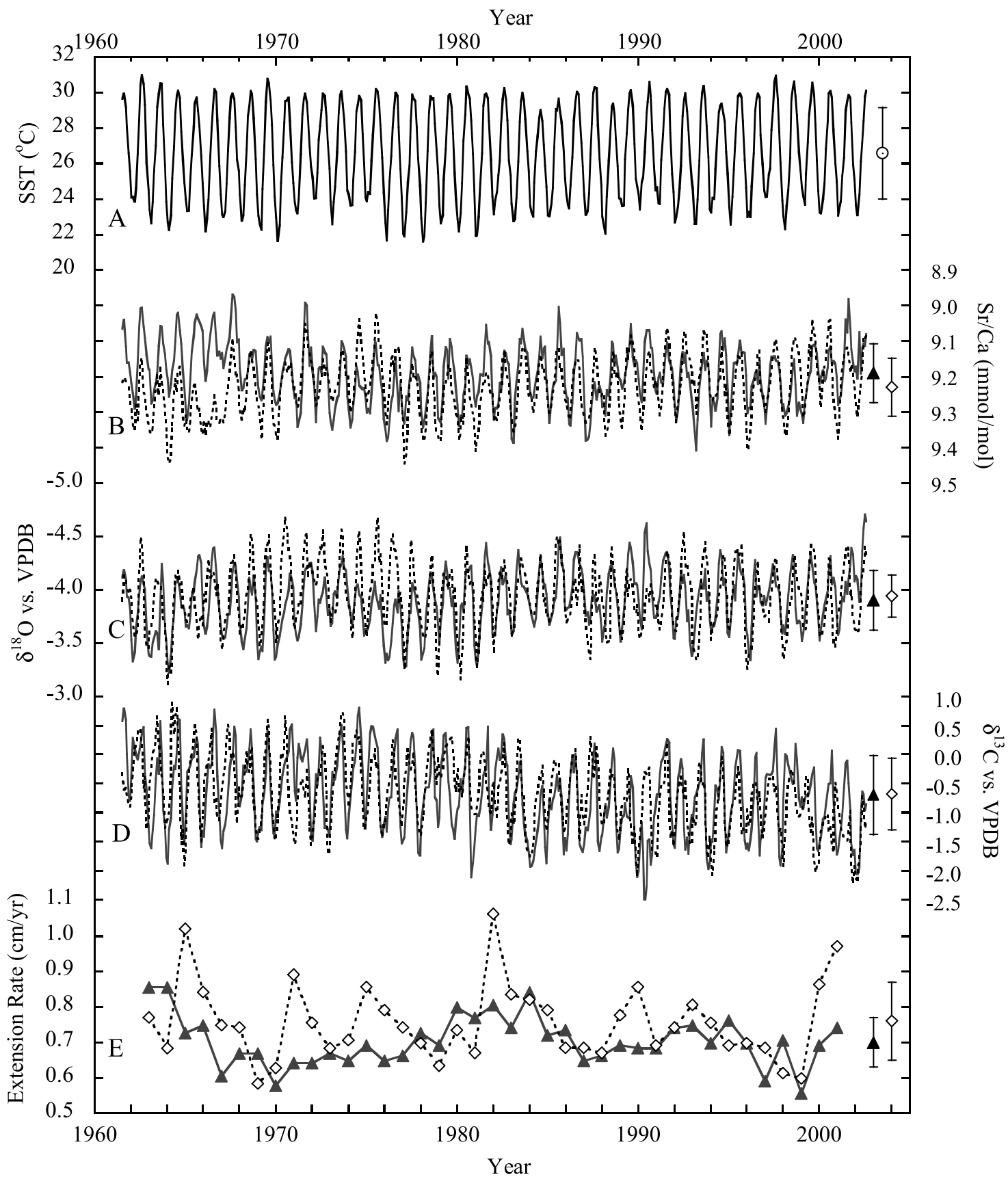

Figure 4. Time series (1961-2002) of (a) adjusted SST, (b) coral Sr/Ca, (c) coral $\delta^{18} \mathrm{O}$, (d) coral $\delta^{13} \mathrm{C}$, and (e) annual extension rate. Data from coral core LK1 (shaded lines, triangles) and LK23 data (dashed lines, diamonds) are shown in Figures $4 \mathrm{~b}-4 \mathrm{e}$. Annual extension rates are measured from the preceding summer (i.e., 1978 is summer of 1977 to summer 1978). Mean values of each geochemical variable for each core are to the right of each geochemical time series. Error bars on mean values are $\pm 1 \sigma$. Standard errors of each mean value are reported in the text.

absolute value between each monthly value in the two time series; this value drops almost in half to $0.11 \pm 0.01 \%$ o $\left(\sigma_{\bar{x}}\right)$ at periods greater than 2 years. The difference in monthly $\delta^{18} \mathrm{O}$ values reaches a maximum around 1976. This difference is explained in part by the larger amplitude of LK23 compared with LK1 from 1970 to 1978 (Figure 4). This may be explained by the larger growth rates exhibited by LK23 over LK1 during this time interval, which implies that periods of higher extension rate are yielding better resolution of the annual cycle. The climatological annual cycle in $\delta^{18} \mathrm{O}$ is characterized by average amplitudes of $0.55 \%$ (LK1) and $0.60 \%$ (LK23) with the most negative $\delta^{18} \mathrm{O}$ values occurring in August and the most positive values in February, which corresponds with the warmest 
Table 1. Summary of Geochemical Data for Corals LK1 and LK23 for 1961-2002 a

\begin{tabular}{llccccc}
\hline & \multicolumn{3}{c}{ Mean Plus/Minus Standard Error } & & \multicolumn{3}{c}{ Amplitudes } \\
\cline { 2 - 6 } & \multicolumn{1}{c}{$\delta^{13} \mathrm{C}$} & $\delta^{18} \mathrm{O}$ & $\mathrm{Sr} / \mathrm{Ca}$ & & $\delta^{13} \mathrm{C}$ & $\delta^{18} \mathrm{O}$ \\
\hline LK 1 & $-0.70 \pm 0.06$ & $-3.90 \pm 0.02$ & $9.193 \pm 0.007$ & & 1.3 & 0.55 \\
LK 23 & $-0.68 \pm 0.05$ & $-3.94 \pm 0.03$ & $9.230 \pm 0.004$ & & 1.1 & 0.191 \\
Average & $-0.69 \pm 0.05$ & $-3.92 \pm 0.02$ & $9.211 \pm 0.006$ & & 1.2 & 0.65 \\
Mean Monthly & $0.46 \pm 0.03$ & $0.21 \pm 0.02$ & $0.068 \pm 0.005$ & & 0.22 & 0.194 \\
$\quad$ Difference & & & & & 0.192 \\
\end{tabular}

${ }^{a}$ Mean monthly difference between the cores (LK1-LK23) is calculated as the average of the absolute value of monthly differences. Amplitudes are calculated as the difference between the maximum and minimum climatological values. Isotope values are reported in \%o $\mathrm{VPDB}$ and $\mathrm{Sr} / \mathrm{Ca}$ is reported in $\mathrm{mmol} / \mathrm{mol}$.

and coolest months of the year. The coincidence of minimum and maximum values in $\delta^{18} \mathrm{O}$ and SST was not forced in the creation of the age model for each of these time series.

[21] Mean $\mathrm{Sr} / \mathrm{Ca}$ values for the two cores from 1961 to 2002 are $9.193 \pm 0.007\left(\sigma_{\bar{x}}\right)$ and $9.230 \pm 0.007\left(\sigma_{\bar{x}}\right) \mathrm{mmol} /$ mol and the $0.037 \mathrm{mmol} / \mathrm{mol}$ difference in means is significant $(\mathrm{p}>0.95)$. Amplitudes of the seasonal cycle based on the climatological cycle are comparable between the two coral $\mathrm{Sr} / \mathrm{Ca}$ records at $\sim 0.19 \mathrm{mmol} / \mathrm{mol}$. The absolute value of difference between each monthly value in the two time series is $0.068 \pm 0.004\left(\sigma_{\bar{x}}\right) \mathrm{mmol} / \mathrm{mol}$ and after removing variability occurring at $<2$ years the value drops to $0.055 \pm 0.005\left(\sigma_{\bar{x}}\right) \mathrm{mol} / \mathrm{mol}$. The variances of each time series are statistically equivalent $(F$ test, $\mathrm{p}>0.95)$ suggesting that both records are capturing the same variability despite difference in the means taken over the entire time interval of study.

\subsection{Geochemical Relationships With SST}

[22] The regression relationship developed for the twocore averaged (i.e., stacked) monthly time series of $\delta^{18} \mathrm{O}$ SST and Sr/Ca-SST over the 41 years of monthly variation are as follows:

$$
\begin{aligned}
\delta^{18} \mathrm{O} & =-0.101( \pm 0.005) * \mathrm{SST}-1.24( \pm 0.13) \\
{[\mathrm{n}} & =494, \mathrm{R}=-0.84]
\end{aligned}
$$

$$
\begin{aligned}
& \mathrm{Sr} / \mathrm{Ca}=-0.0282( \pm 0.002) * \mathrm{SST}+9.962( \pm 0.035) \\
& \quad[\mathrm{n}=494, \mathrm{R}=-0.86]
\end{aligned}
$$

Individual regression equations for both $\delta^{18} \mathrm{O}$ and $\mathrm{Sr} / \mathrm{Ca}$ on SST are summarized in Tables 2 and 3. Generating the regression using just the maximum and minimum values each year yields a slope within error bars $(2 \sigma)$ for $\delta^{18} \mathrm{O}-\mathrm{SST}$ $(-0.091 \pm 0.01, \mathrm{n}=83, \mathrm{R}=-0.93)$ and a slightly more negative slope for Sr/Ca-SST $(-0.0298 \pm 0.004, \mathrm{n}=83, \mathrm{R}=$ $-0.95)$. While the relationships with SST are not significantly different between LK1, LK23, or in the averaged data, they are significantly different from the equations of both Leder et al. [1996] and Swart et al. [2002] (Table 2). In fact, application of the $\mathrm{Sr} / \mathrm{Ca}-\mathrm{SST}$ relationship of Swart et al. [2002] to the Looe Key data yields a mean SST that is $>6^{\circ} \mathrm{C}$ less than observed SST and merits closer inspection of this result. Regression equations of both $\delta^{18} \mathrm{O}$ and $\mathrm{Sr} / \mathrm{Ca}$ with the $\sim 7$ years of in situ SST reveal statistically equivalent relationships to the regression equations generated using gridded, composite SST. The difference in mean $\delta^{18} \mathrm{O}$ values between cores translates to a difference in SST of $\sim 0.4^{\circ} \mathrm{C}$ using the stacked $\delta^{18} \mathrm{O}$-SST equation and is within our analytical error. However, the overall difference in the mean $\mathrm{Sr} / \mathrm{Ca}$ values between the two cores equates to $1.3^{\circ} \mathrm{C}$ using the stacked $\mathrm{Sr} / \mathrm{Ca}-\mathrm{SST}$ equation. From a mean annual (August-July) perspective (Figure 5), there are

\begin{tabular}{|c|c|c|c|c|c|c|c|}
\hline & \multicolumn{2}{|c|}{ RMA } & \multicolumn{2}{|c|}{ OLS } & \multirow[b]{2}{*}{$\mathrm{R}$} & \multirow[b]{2}{*}{$\mathrm{SE}_{\mathrm{m}}$} & \multirow[b]{2}{*}{$\mathrm{SE}_{\mathrm{b}}$} \\
\hline & $\mathrm{m}$ & $\mathrm{b}$ & $\mathrm{m}$ & $\mathrm{b}$ & & & \\
\hline $\begin{array}{l}\text { LK } 1 \\
\text { LK23 } \\
\text { Stack } \\
\text { Stack, } \max / \min \\
\text { Leder et al. }[1996]\end{array}$ & $\begin{array}{l}-0.108 \\
-0.119 \\
-0.101 \\
-0.091\end{array}$ & $\begin{array}{l}-1.02 \\
-0.76 \\
-1.24 \\
-1.52\end{array}$ & $\begin{array}{l}\delta^{18} O-S S \\
-0.079 \\
-0.090 \\
-0.085 \\
-0.084 \\
-0.22\end{array}$ & $\begin{array}{l}-1.79 \\
-1.56 \\
-1.67 \\
-1.69 \\
1.18\end{array}$ & $\begin{array}{l}-0.73 \\
-0.75 \\
-0.84 \\
-0.93\end{array}$ & $\begin{array}{l} \pm 0.007 \\
\pm 0.008 \\
\pm 0.005 \\
\pm 0.004 \\
\pm 0.02\end{array}$ & $\begin{array}{l} \pm 0.18 \\
\pm 0.19 \\
\pm 0.13 \\
\pm 0.10 \\
\pm 0.10\end{array}$ \\
\hline $\begin{array}{l}\text { LK } 1 \\
\text { LK23 } \\
\text { Stack } \\
\text { Stack, max/min } \\
\text { Swart et al. }[2002]\end{array}$ & $\begin{array}{l}-0.0324 \\
-0.0321 \\
-0.0282 \\
-0.0298\end{array}$ & $\begin{array}{l}10.054 \\
10.083 \\
9.962 \\
10.000\end{array}$ & $\begin{array}{l}\mathrm{Sr} / \mathrm{Ca}-\mathrm{SS} \\
-0.0233 \\
-0.0252 \\
-0.0243 \\
-0.0284 \\
-0.0471 \\
\end{array}$ & $\begin{array}{l}9.812 \\
9.900 \\
9.856 \\
9.962 \\
10.165 \\
\end{array}$ & $\begin{array}{l}-0.72 \\
-0.79 \\
-0.86 \\
-0.95 \\
-0.88 \\
\end{array}$ & $\begin{array}{l} \pm 0.002 \\
\pm 0.002 \\
\pm 0.002 \\
\pm 0.002\end{array}$ & $\begin{array}{l} \pm 0.054 \\
\pm 0.048 \\
\pm 0.035 \\
\pm 0.054\end{array}$ \\
\hline
\end{tabular}
episodes of general agreement, yet neither LK1 nor LK23 are precise recorders of temperature over the entire time

Table 2. Regression Relationships for $\delta^{18} \mathrm{O}-\mathrm{SST}$ and Sr/Ca-SST From 1961 to $2002^{\mathrm{a}}$

${ }^{\mathrm{a}}$ Errors are in $1 \sigma ; \mathrm{n}=494$ for all Looe Key equations except the maximum/minimum (max/min) regression is $\mathrm{n}=83$. Reduced major axis (RMA) and ordinary least squares (OLS) equations are provided for comparison along with literature values. SE denotes standard error. Equations are in the form $\left(\delta_{\mathrm{c}}-\right.$ $\left.\delta_{\mathrm{w}}\right)=\mathrm{mSST}+\mathrm{b}$ and $\mathrm{Sr} / \mathrm{Ca}=\mathrm{mSST}+\mathrm{b}$. 
Table 3. Pearson Product Moment Correlation Coefficients ${ }^{\mathrm{a}}$

\begin{tabular}{|c|c|c|c|c|c|c|c|}
\hline & \multicolumn{3}{|c|}{ LK1 } & \multicolumn{3}{|c|}{ LK23 } & \multirow[b]{2}{*}{ SST } \\
\hline & $\delta^{13} \mathrm{C}$ & $\delta^{18} \mathrm{O}$ & $\mathrm{Sr} / \mathrm{Ca}$ & $\delta^{13} \mathrm{C}$ & $\delta^{18} \mathrm{O}$ & $\mathrm{Sr} / \mathrm{Ca}$ & \\
\hline LK1 $\delta^{13} \mathrm{C}$ & & 0.09 & & & -0.14 & -0.02 & \\
\hline $\mathrm{LK} 1 \mathrm{Sr} / \mathrm{Ca}$ & $\begin{array}{l}-0.30 \\
-0.25\end{array}$ & 0.67 & & 0.02 & $\begin{array}{l}0.09 \\
0.09\end{array}$ & $\begin{array}{l}0.20 \\
-0.04\end{array}$ & -0. \\
\hline LK23 $\delta^{13} \mathrm{C}$ & 0.59 & -0.19 & -0.21 & & 0.05 & 0.32 & -0.04 \\
\hline LK23 $\delta^{18} \mathrm{O}$ & -0.45 & 0.57 & 0.56 & -0.28 & & 0.51 & -0.2 \\
\hline $\mathrm{LK} 23 \mathrm{Sr} / \mathrm{Ca}$ & 0.35 & 0.63 & 0.53 & -0.14 & 0.78 & & -0.3 \\
\hline SST & 0.49 & -0.73 & -0.72 & 0.38 & -0.75 & -0.79 & \\
\hline
\end{tabular}

${ }^{\mathrm{a} B o l d}$ values indicate $\mathrm{p}>0.99$. Italicized (nonitalicized) values are correlation coefficients between anomalies (original monthly time series).

interval. The greatest monthly offset between the two $\mathrm{Sr} / \mathrm{Ca}$ records occurs around 1965 and equates to $\sim 7^{\circ} \mathrm{C}$ (Figure 4) and is clearly not indicative of actual SST conditions experienced in situ on the reef.

[23] Direct regression of $\delta^{18} \mathrm{O}$ onto SST does not take into account variations in $\delta_{\mathrm{w}}$ which can either contribute to or subtract from estimates of SST. Application of the equation of Leder et al. [1996] to the Looe Key data requires a substitution of $0.8 \%$ for $\delta_{w}$ to obtain the correct mean value of instrumental SST. Additional variation in $\delta_{w}$ must occur to account for the difference in variance between $\delta^{18} \mathrm{O}-\mathrm{SST}$ and instrumental SST time series. The range in salinity from the quarterly measurements taken at the reef site 19952004 (2.1 psu) equates to a range in $\delta_{w}$ of $\sim 0.6-0.8 \%$ o using a salinity $-\delta_{\mathrm{w}}$ relationship from southern Florida Bay [Swart et al., 1999].
[24] We investigate the potential causes for the $\delta^{18} \mathrm{O}-\mathrm{SST}$ and $\mathrm{Sr} / \mathrm{Ca}-\mathrm{SST}$ differences between our work and previous calibrations as well as some of the larger geochemical excursions in the time series in sections 4.2 and 4.3 .

\subsection{Water Chemistry and the Relationship Between Coral $\delta^{18} \mathrm{O}$ and $\mathrm{Sr} / \mathrm{Ca}$}

[25] The monthly $\delta^{18} \mathrm{O}$ and $\mathrm{Sr} / \mathrm{Ca}$ time series covary in cores LK 1 and LK23 ( $\mathrm{R}=0.67$ and 0.78 , respectively). This is also true of the averaged time series and produces the relationship:

$$
\begin{aligned}
\mathrm{Sr} / \mathrm{Ca}(\mathrm{mmol} / \mathrm{mol})= & 0.28( \pm 0.02) * \delta^{18} \mathrm{O}(\% \text { VPDB }) \\
& +10.31( \pm 0.05),[\mathrm{n}=494, \mathrm{R}=0.85]
\end{aligned}
$$

The relationship between $\delta^{18} \mathrm{O}$ and $\mathrm{Sr} / \mathrm{Ca}$, \%owhen cast in terms of anomalies from the annual cycle, accounts for over $30 \%(\mathrm{R}=0.55, \mathrm{p} \geq 0.99)$ of the variance between the two records and is compelling considering that SST accounts for $<11 \%$ of the variance $(\mathrm{R}=-0.33,-0.34, \mathrm{p} \geq 0.99, \mathrm{Sr} / \mathrm{Ca}$ and $\delta^{18} \mathrm{O}$, respectively; Figure 6). This observation requires an explanation that can simultaneously affect both $\delta^{18} \mathrm{O}$ and $\mathrm{Sr} / \mathrm{Ca}$.

[26] Variations in water chemistry independent of temperature have been shown to affect coralline $\mathrm{Sr} / \mathrm{Ca}$ [de Villiers et al., 1994, 1995; Shen et al., 1996] and $\delta^{18} \mathrm{O}$ [Linsley et al., 1999; Le Bec et al., 2000]. We investigate this possibility by isolating the covariation between $\mathrm{Sr} / \mathrm{Ca}$ and $\delta^{18} \mathrm{O}$

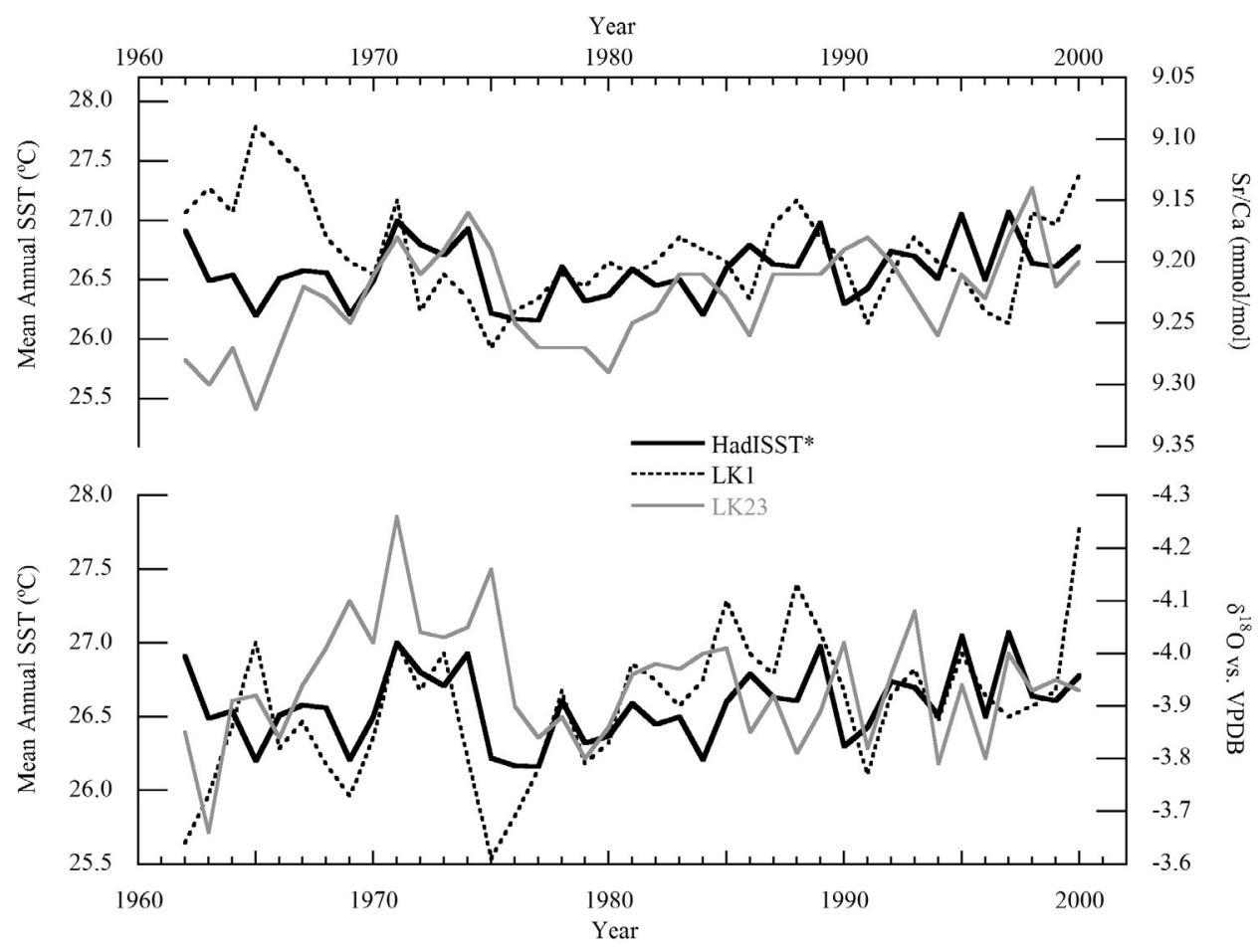

Figure 5. Mean annual (August-July) values of SST: (top) Sr/Ca and (bottom) $\delta^{18} \mathrm{O}$ for LK1 (dashed line) and LK23 (shaded line) compared with SST (solid line). Mean annual SST is scaled to the stacked mean annual relationship between both LK1 and LK23. 


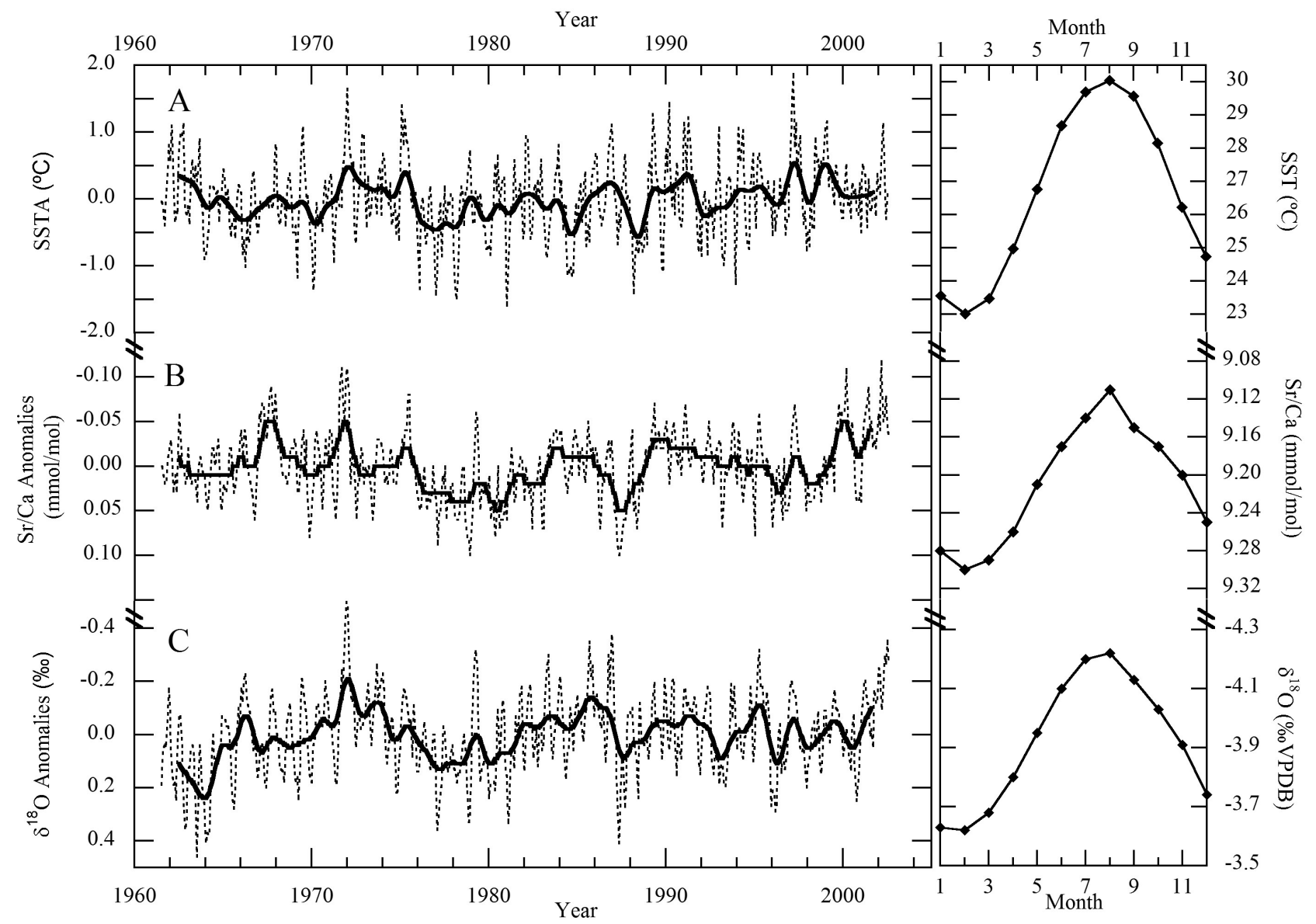

Figure 6. Time series of anomalies in (a) SST, (b) stacked coral $\mathrm{Sr} / \mathrm{Ca}$, and (c) stacked coral $\delta^{18} \mathrm{O}$. Anomalies were calculated as differences from the monthly climatological means calculated for the 1961-2002 interval (right). The solid line in Figures $6 \mathrm{a}-6 \mathrm{c}$ is the monthly record filtered with a 25 -point convolution-type filter with a half-amplitude response at 24 months to remove higher-frequency variability. Note the stronger relationship between $\mathrm{Sr} / \mathrm{Ca}$ and $\delta^{18} \mathrm{O}$ anomalies despite a weaker relationship with SSTA.

by removing the contribution of SST. For coral $\delta^{18} \mathrm{O}$ this was accomplished by calculating $\delta_{\mathrm{w}}$ using the relationships of Leder et al. [1996] (equation (4)):

$$
\delta_{\text {water }}=\frac{(S S T-5.33)}{4.519}+\delta_{\text {coral }}
$$

The general thermodynamic relationship describing the distribution of trace elements between solid $\left(\mathrm{Sr} / \mathrm{Ca}_{\text {aragonite }}\right)$ and liquid $\left(\mathrm{Sr} / \mathrm{Ca}_{\mathrm{w}}\right)$ phases has been described by Kinsman and Holland [1969] is expressed by the distribution coefficient $\mathrm{K}\left(\mathrm{T}^{\circ} \mathrm{C}\right)$ (equation (5)). Smith et al. [1979] later refined the relationship between $\mathrm{K}(\mathrm{T})$ and temperature specifically for coral, as opposed to inorganic aragonite, and produced equation (6).

$$
\begin{gathered}
K(T)=\frac{S r / C a_{\text {aragonite }}}{S r / C a_{w}} \\
K(T)=1.30-0.0094^{*} T
\end{gathered}
$$

A simple rearrangement and substitution allows us to solve for a variable $\mathrm{Sr} / \mathrm{Ca}$ of the water:

$$
S r / C a_{\text {water }}=\frac{S r / C a_{\text {coral }}}{1.30-0.0094^{*} T}
$$

Using equations (4) and (7) we calculate mean seawater $\mathrm{Sr} /$ $\mathrm{Ca}$ and $\delta^{18} \mathrm{O}$ to be $8.775 \pm 0.013 \mathrm{mmol} / \mathrm{mol}$ and $0.79 \pm$ $0.03 \%$, respectively, over the 41 years of the coral time series (Figure 7a). The calculated parameters of $\delta_{\mathrm{w}}$ and $\mathrm{Sr} /$ $\mathrm{Ca}_{\mathrm{w}}$ are positively related by the relationship

$$
\begin{array}{r}
\mathrm{Sr} / \mathrm{Ca}_{\mathrm{w}}(\mathrm{mmol} / \mathrm{mol})=0.39 * \delta_{\mathrm{w}}(\% \mathrm{SMOW})+8.47, \\
{\left[\mathrm{n}=494, \mathrm{r}^{2}=0.89\right]}
\end{array}
$$

Synchronous changes in $\delta_{\mathrm{w}}$ and $\mathrm{Sr} / \mathrm{Ca}_{\mathrm{w}}$ over the annual cycle imply a common forcing $(\mathrm{R}=0.94 \mathrm{p}>0.999)$. Closer inspection of the anomalies from the annual cycle also show a strong degree of covariance $(\mathrm{R}=0.64, \mathrm{p}>0.999$; Figures $7 b$ and $7 c$ ). 


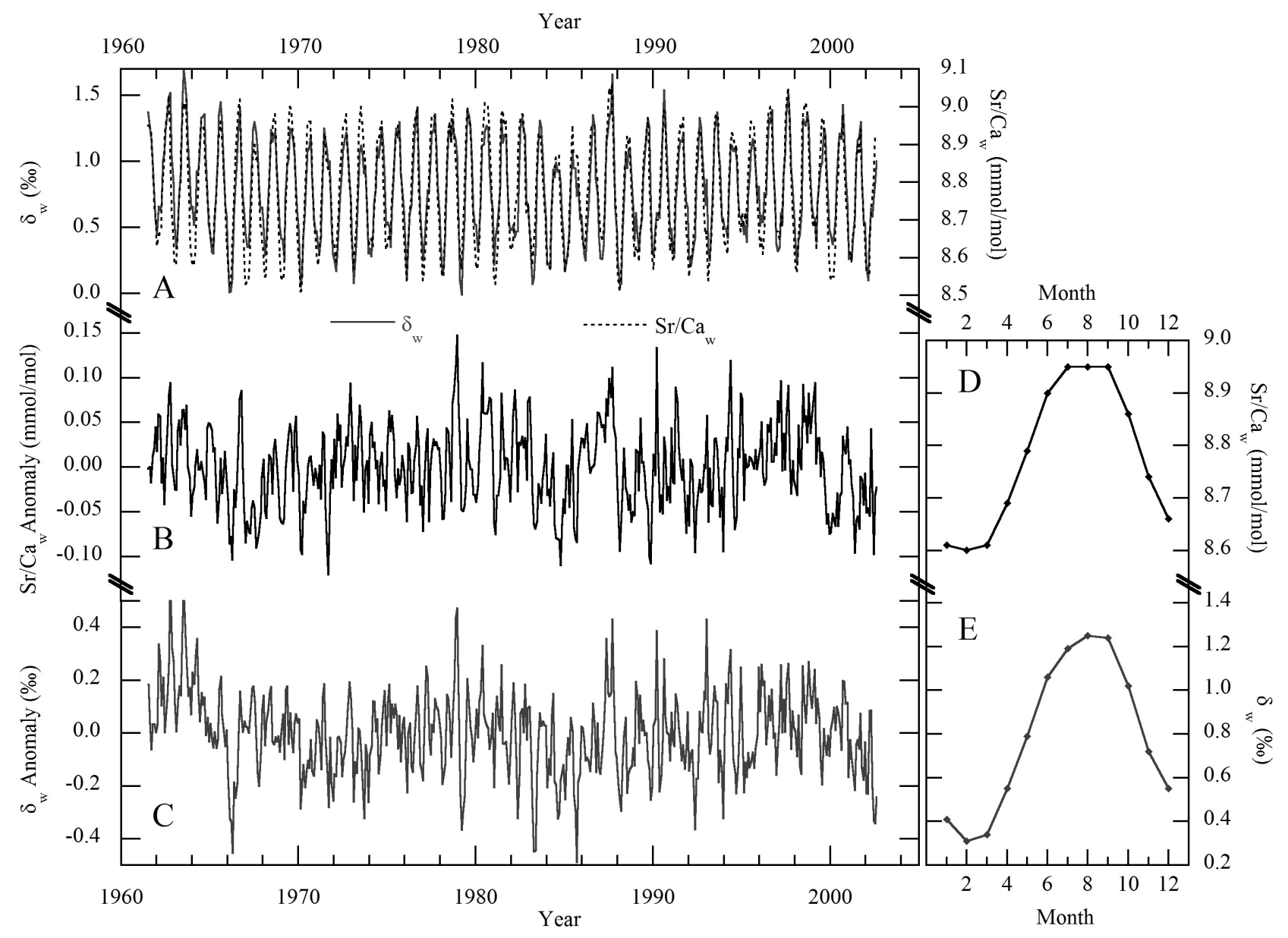

Figure 7. Calculated values of seawater (a) $\delta^{18} \mathrm{O}\left(\delta_{\mathrm{w}}\right.$, solid line) and $\mathrm{Sr} / \mathrm{Ca}\left(\mathrm{Sr} / \mathrm{Ca}_{\mathrm{w}}\right.$, dashed line) and (b) $\delta^{18} \mathrm{O}$ and (c) $\mathrm{Sr} / \mathrm{Ca}$ anomalies based on the stacked coral record. $\mathrm{Sr} / \mathrm{Ca} a_{w}$ is calculated using the combined relationships of Kinsman and Holland [1969] and Smith et al. [1979]: $\mathrm{Sr} / \mathrm{Ca}_{\mathrm{w}}=\mathrm{Sr} / \mathrm{Ca}_{\text {coral }} /(1.30-$ 0.0094(SST)). Seawater $\delta^{18} \mathrm{O}$ is calculated by solving for $\delta_{\mathrm{w}}$ using the equation of Leder et al. [1996]. Average annual cycles of predicted (d) $\mathrm{Sr} / \mathrm{Ca}_{\mathrm{w}}$ and (e) $\delta_{\mathrm{w}}$ calculated from the coral record and instrumental SST for the time period 1961-2002. The timing of the curves is such that they impart a signal opposite to that imposed by temperature.

[27] Interestingly, the annual cycle of both $\mathrm{Sr} / \mathrm{Ca}_{\mathrm{w}}$ and $\delta_{\mathrm{w}}$ moves out of phase from the annual temperature cycle (Figures $7 \mathrm{~d}$ and $7 \mathrm{e}$ ). In effect, this acts to suppress the annual cycle of both coral $\mathrm{Sr} / \mathrm{Ca}$ and $\delta^{18} \mathrm{O}$ (i.e., more positive $\mathrm{Sr} / \mathrm{Ca}_{\mathrm{w}}$ values in the summer will cause more apparent negative temperatures) and is consistent with the observations of Halley et al. [1994]. Thus application of our calibration equations to corals in an environment where the relationship between the timing of temperature and water chemistry is not as strong or absent entirely will act to inflate the amplitude of the annual cycle. The subtractive effect of $\delta_{\mathrm{w}}$ on coral $\delta^{18} \mathrm{O}$ in an environment where SST and salinity are in phase simply prevents the generation of the full annual cycle in temperature when measurements of $\delta_{\mathrm{w}}$ are absent.

[28] Age model construction, which fixes maximum (minimum) $\mathrm{Sr} / \mathrm{Ca}$ with minimum (maximum) SST, assumes that $\Delta \mathrm{SST} \gg \Delta \mathrm{Sr} / \mathrm{Ca}_{\mathrm{w}}$. However, if this is not true, or if water chemistry variations change the apparent timing of the
$\mathrm{Sr} / \mathrm{Ca}$ peak, then our SST assessment will be biased. Therefore we have also developed an independent age model for LK23 that makes no a priori assumptions about the relationship between $\mathrm{Sr} / \mathrm{Ca}$ and SST. Annual highdensity bands in Montastraea are generally formed during the summer months, although the exact timing of such banding can vary between July and September in the Florida Keys [Hudson et al., 1976; Leder et al., 1991]. Our alternate age model assumes that high-density skeletal bands form in August, the month of warmest SST. Calibration results of both $\mathrm{Sr} / \mathrm{Ca}$ and $\delta^{18} \mathrm{O}$ with SST from this density-based age model are consistent (within error) with the slopes obtained from using $\mathrm{Sr} / \mathrm{Ca}-\mathrm{SST}$ age model.

\section{Discussion}

\subsection{Intercoral Geochemical Comparisons}

[29] The LK1 and LK23 $\delta^{13} \mathrm{C}$ time series are largely in agreement with one another at both an annual and decadal 
scale. The $\delta^{13} \mathrm{C}$ records of both corals exhibit a long-term decreasing trend on the order of $-0.02 \%$ o $/$ year which is close to the estimated change $(-0.026 \%$ oryear $)$ in the $\delta^{13} \mathrm{C}$ of dissolved organic carbon (DIC) because of the Suess effect in the Atlantic from 1950 to 1993 [Kortzinger et al., 2003]. Long-term changes in the DIC pool of this area have also been recorded by other corals in this region [Swart et al., 1996a, 1996b], but without direct water measurements of DIC for comparison it remains only a casual correlation to attribute this solely to the Suess effect and ignore the effects of potential land use changes [Halley et al., 1994].

[30] The overall mean $\delta^{18} \mathrm{O}$ of LK1 and LK23 differs by $0.04 \%$, which is within our analytical error, and is significantly less than the range of other worker's multidecadal estimates in Porites corals collected at the same reef $(\sim 0.15-0.4 \%$ ) in the central and western tropical Pacific [Guilderson and Schrag, 1999; Linsley et al., 1999; Cobb et al., 2003; Stephans et al., 2004]. Our results are also consistent with the shorter-term studies on Montastraea in Puerto Rico and Biscayne Bay, Florida, that have reported differences of $0.08 \%$ [Watanabe et al., 2002] and $0.22 \%$ [Leder et al., 1996]. Guilderson and Schrag [1999] suggest such offsets are due to the time-varying kinetic equilibrium of the coral and concluded that decadal-scale or secular trends reflect environmental change rather than a variation in isotopic disequilibria due to variable calcification rates.

[31] The $\mathrm{Sr} / \mathrm{Ca}$ records of LK1 and LK23 contain the same amount of variance, but have different means. There are intervals of good agreement between the corals and other intervals of substantial difference. The difference in overall mean $\mathrm{Sr} / \mathrm{Ca}$ value between the cores is exacerbated by the divergence of the records before 1968 and especially in the 1965-1967 portion of LK23. Closer inspection of this time period reveals the least dense band in LK23 formed in 1966 and may be linked to absence of a fully developed geochemical summer in this year. An alternative explanation of the pre-1968 offset in means could possibly be related to the unavoidable consequence of two-dimensional sampling of a coral that exhibits three-dimensional growth. Variations of the thecal wall into and out of the plane of the slab may impart some bias in the results; however, it is unlikely given the reproducibility of the record outside of this time interval. Whatever the reason is, given the close proximity of these two corals, it seems logical that some process beyond environmental forcing is responsible for this unexpected result. The larger difference in $\mathrm{Sr} / \mathrm{Ca}$ relative to $\delta^{18} \mathrm{O}$ or $\delta^{13} \mathrm{C}$ suggests that differences in $\mathrm{Sr} / \mathrm{Ca}$ between corals may be somewhat reflective of the individual nature of some corals. The ultimate explanation for the deviation in the $\mathrm{Sr} / \mathrm{Ca}$ records at this time period must not only account for the difference in $\mathrm{Sr} / \mathrm{Ca}$, but must also consider the notable consistency between corals in both the $\delta^{18} \mathrm{O}$ and $\delta^{13} \mathrm{C}$ records during this same time interval.

\subsection{Growth Impacts on Coral Geochemistry}

[32] The impact of growth-related processes on coral $\delta^{18} \mathrm{O}$ and, more recently, coral $\mathrm{Sr} / \mathrm{Ca}$ has been studied, but no consensus has been reached. Observations of invariant coral $\delta^{18} \mathrm{O}$ or $\mathrm{Sr} / \mathrm{Ca}$ with extension rate [Shen et al., 1996; Alibert and McCulloch, 1997; Gagan et al., 1998; Marshall and
McCulloch, 2002; Mitsuguchi et al., 2003; Allison and Finch, 2004] contrast with observations of variable $\delta^{18} \mathrm{O}$ and/or $\mathrm{Sr} / \mathrm{Ca}$ with extension rate [Land et al., 1975; McConnaughey, 1989b; de Villiers et al., 1995; Cohen et al., 2001; Goodkin et al., 2005]. We explore two proposed mechanisms that may explain these reports as they pertain to this study.

\subsubsection{Sampling Considerations and Growth Effects}

[33] The resolution at which a coral skeleton is sampled for geochemical analysis has an effect on the amplitude of the annual cycle that is recovered [Leder et al., 1996; Quinn et al., 1996; Swart et al., 1996c; Crowley et al., 1999; Watanabe et al., 2002]. The reason for this can be twofold: The combination of vertical extension and calcification can change the amount of material deposited to the skeleton throughout the year. On the basis of the results of both Mendes [2004] and Leder et al. [1996] we infer the amount of material deposited to the skeleton to be greater over a shorter distance in the summer than in other times of the year, which in turn agrees with the timing of the highdensity bands [Highsmith, 1979]. The geochemical implication of this growth regime is a time-averaging effect resulting from the increased amount of material laid down over shorter distances in the core. This implies a potential sampling bias against the slower extending times of the year (high-density portions), with Montastraea extending slowest in the summer [Swart et al., 1996c; Mendes, 2004]. Hence variations in the amplitude of the geochemical signal may arise because of a relative oversampling of nonsummer months and undersampling of summer months. Leder et al. [1996] recommend sampling the coral skeleton on the order of 50-55 times per year to capture the full range of seawater temperatures (i.e., both maximum and minimum temperatures experienced on the reef at a quasi-weekly resolution) using coral $\delta^{18} \mathrm{O}$ in regions that exhibit a large seasonal range of seawater temperatures $\left(\sim 9^{\circ} \mathrm{C}\right.$; Florida Keys). Data from both Leder et al. [1996] and Watanabe et al. [2002] document a disproportionate reduction in estimated SST amplitude with decreasing sampling resolution (i.e., a proportionally larger reduction in amplitude with coarser sampling density). This disproportionate reduction in amplitude has been shown to change the slope in the $\delta^{18} \mathrm{O}-\mathrm{SST}$ relationship between monthly and annual calibrations [Crowley et al., 1999].

[34] Recovery of the full temperature range may not even be possible in some environments. Halley et al. [1994] sampled a Montastraea annularis from the Florida Keys at 70 samples per year and were still unsuccessful in recovering the expected amplitude in $\delta^{18} \mathrm{O}$ based upon the observed temperature range. They concluded that isotopically heavy values of $\delta^{18} \mathrm{O}$ imported from Florida Bay subtract from the temperature signal. In such an environment it should be expected that regression of temperature against $\delta^{18} \mathrm{O}$ would yield different slopes. We have also collected data taken from LK23 at a resolution of 40 samples per year (Figure 8). Owing to the small amount of coral powder generated with this higher sampling resolution, it was not possible to make paired determinations, but rather elemental and isotopic values were obtained from different sampling paths chosen to overlap the same time period. Average amplitudes from 


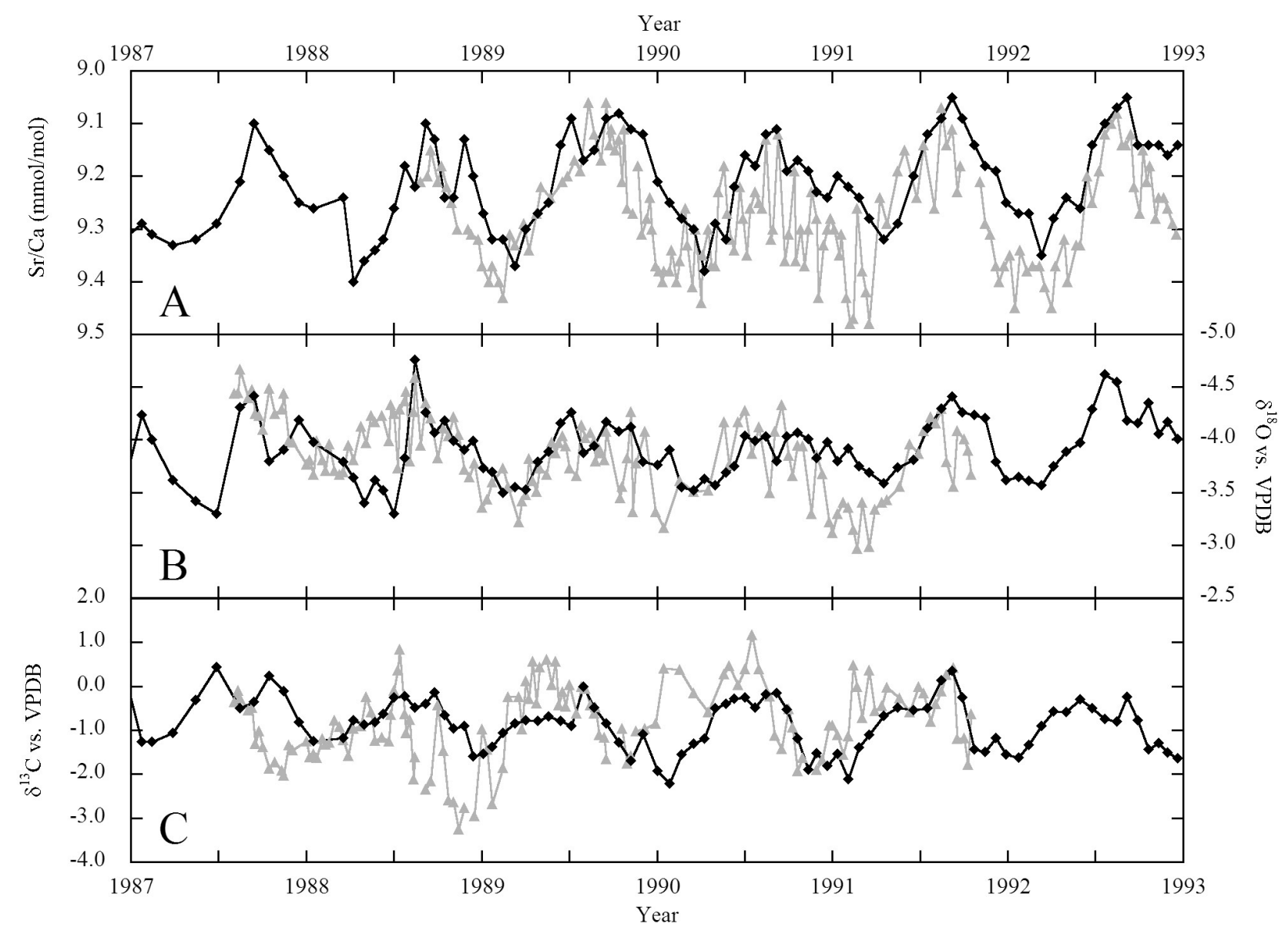

Figure 8. Comparison of drilling $\sim 40$ samples per year (diamonds) with sampling 14 samples per year (triangles) on (a) $\mathrm{Sr} / \mathrm{Ca}$, (b) $\delta^{18} \mathrm{O}$, and (c) $\delta^{13} \mathrm{C}$.

the samples obtained at 14 samples per year are $78 \%, 75 \%$ and $60 \%$ of the amplitudes of the 40 samples per year transects for $\mathrm{Sr} / \mathrm{Ca}, \delta^{18} \mathrm{O}$ and $\delta^{13} \mathrm{C}$, respectively, and are much noisier in character. Regression of the high-resolution data, resampled to monthly values, against SST yields similarly low slope coefficients compared to previously published slopes $(-0.0355 \pm 0.003, \mathrm{Sr} / \mathrm{Ca} ;-0.122 \pm$ $\left.0.013, \delta^{18} \mathrm{O}\right)$. These results are in line with the conclusions of Halley et al. [1994] in that increased sampling resolution does not yield geochemical amplitudes expected based on temperature alone for reefs adjacent to the influence of Florida Bay.

[35] Continuous sampling at a constant depth increment down core leads to a variable sampling rate through the core because of the changing extension rate of the coral. This equates to sampling resolutions ranging from 10-22 samples/year in this study. Leder et al. [1996] sampled their Montastraea annularis coral at roughly weekly resolution (50-55 samples/year of growth) in an effort to avoid the nonlinear extension effects discussed earlier. We investigate the difference between our calibration equations and those of Leder et al. [1996] and Swart et al. [2002] as a function of sampling density by looking at the three warmest month calibrations (summer; July-September; presumed slowest extending portion of the year) and contrasting them with the three coldest month's calibrations (winter; January-March). Winter was selected to minimize any potential overlap due to age model errors. The slopes of winter-and summerbased calibrations from the averaged records for both $\delta^{18} \mathrm{O}$ and $\mathrm{Sr} / \mathrm{Ca}$ are significantly different from each other $(\mathrm{p}>$ 0.95 ) with winter calibrations having slopes that are more similar to the slope of the $\delta^{18} \mathrm{O}-\mathrm{SST}$ relationship determined via weekly sampling over the annual growth increment. This suggests a seasonal bias against slower growing times of the year. Notwithstanding the effects of sampling, if high rates of calcification are coupled with sufficiently slow extension rates then even high-resolution (weekly) sampling of the coral skeleton may not be sufficient to capture the potential full amplitude of the geochemical signal.

[36] An additional factor that should be considered in sampling Montastraea is the horizontal variability that exists between different skeletal elements. We generated $\mathrm{Sr} / \mathrm{Ca}$ values across the width of the LK23 slab to assess the variability that may be introduced because of the inclusion of other skeletal elements that, while in the same horizontal plane of the coral relative to the density band, may have 


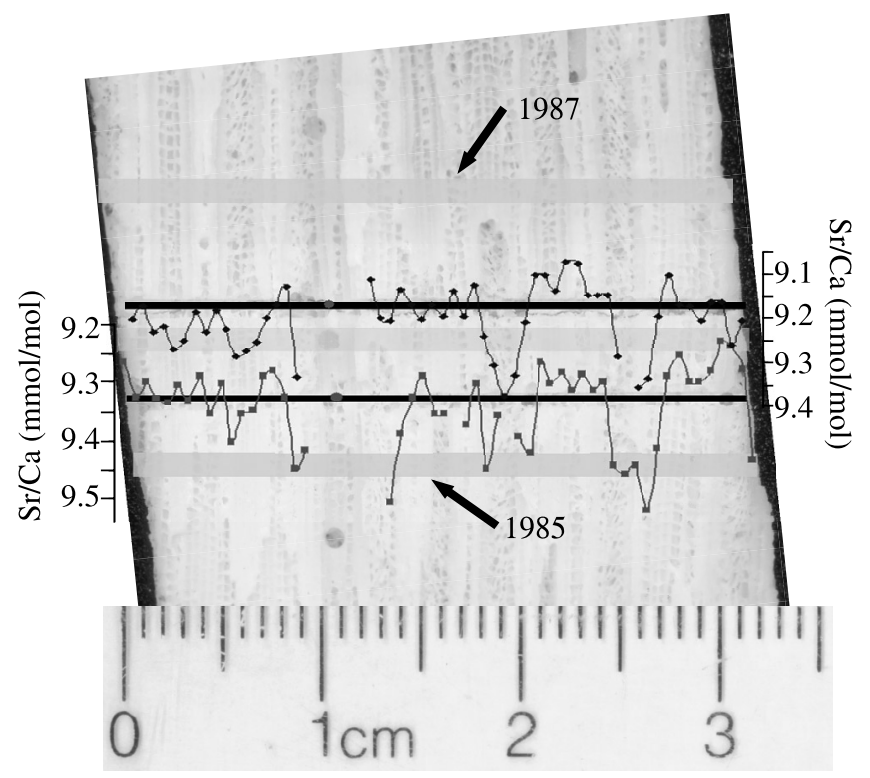

Figure 9. Horizontal variations in $\mathrm{Sr} / \mathrm{Ca}$ across several corallites in LK23. Black horizontal lines indicate drill paths. Shaded bars indicate position of high-density bands. $\mathrm{Sr} / \mathrm{Ca}$ values from the 41-year climatology place the timing of the horizontal transects as September (top) and February (bottom), and this is in general agreement in terms of distance away from high-density bands. Drilling deviations away from the exothecal wall can result in the incorporation of nonideal skeletal elements. These skeletal elements, when taken from a horizontal perspective, are not deposited to the skeleton at the same time during the year or are deposited at a different rate than the exothecal wall.

been deposited at a different time than the exothecal wall. Two transects were sampled (Figure 9), and geochemical values based on the 41-year climatology of the vertically sampled transect place their timing at approximately February and September of 1986 . Values obtained during the vertical sampling are commensurate with values generated from other exothecal walls on the horizontal transect. Variation between corallite elements is large $(1 \sigma=0.07$ $\mathrm{mmol} / \mathrm{mol}$ ) and equates to over $2^{\circ} \mathrm{C}$, highlighting the need for special care when generating long time series. The inclusion of some of the other skeletal elements is undesirable, yet may be an unavoidable reality when generating long time series because of the meandering growth of the corallite through the plane of the slab.

\subsubsection{Kinetic Effects}

[37] Genera-specific differences in mean $\delta^{18} \mathrm{O}$ and $\mathrm{Sr} / \mathrm{Ca}$ have been observed in a multitude of taxa based upon differences in vital effects [Weber and Woodhead, 1970] and average extension rates [Weber, 1973], respectively. Growth-related impacts on Pavona coral $\delta^{18} \mathrm{O}$ and $\mathrm{Sr} / \mathrm{Ca}$ have been reported [McConnaughey, 1989b; de Villiers et al., 1995]. One of the main conclusions drawn by McConnaughey [1989b] is that the fastest growing portions of the skeleton must be sampled because the degree of isotopic variation is too variable in the slower growing portions. Despite these observations in Pavona, the reports of kinetic effects in Porites that are sampled along the major axis of growth are more ambiguous for $\mathrm{Sr} / \mathrm{Ca}$. Conflicting results of ion microprobe analyses of $\mathrm{Sr} / \mathrm{Ca}$ in Porites suggest that either growth rate effects depress mean annual $\mathrm{Sr} / \mathrm{Ca}$ [Cohen and Hart, 2004], or that there is no effect [Allison and Finch, 2004]. Felis et al. [2003] measured pronounced $\delta^{18} \mathrm{O}$ enrichment in Porites at extension rates less than $6 \mathrm{~mm} / \mathrm{yr}$ when examining the maximum axis of growth in a range of different colonies with growth rates of $2-15 \mathrm{~mm} / \mathrm{yr}$; however, in the work of Gagan et al. [1998] two corals each growing at 12 and $22 \mathrm{~mm} / \mathrm{yr}$ at the same location showed no discernable difference in $\delta^{18} \mathrm{O}$ or $\mathrm{Sr} / \mathrm{Ca}$. From these two studies it appears that linear extension rates may have an influence on coral $\delta^{18} \mathrm{O}$ and $\mathrm{Sr} / \mathrm{Ca}$ at the slowest of extension rates, the overall character of the geochemical signal is constant above some threshold level in Porites, and coral geochemical signals recorded in the slowest of extending years in any coral genus and should be viewed with caution.

[38] We explore and attempt to identify the potential impact of skeletal growth parameters upon $\mathrm{Sr} / \mathrm{Ca}$ and $\delta^{18} \mathrm{O}$ in Montastraea recognizing that the body of literature relating geochemical values to extension rates, irrespective of calcification, in Montastraea is grossly limited compared to that of Porites. Comparisons of $\mathrm{Sr} / \mathrm{Ca}-\mathrm{SST}$ and $\delta^{18} \mathrm{O}-\mathrm{SST}$ with skeletal growth parameters yields the highest significant correlations with density $(\mathrm{R}=0.35, \mathrm{R}=0.25, \mathrm{p}>0.99$, respectively) which agrees with the relationship between the timing of high-and low-density band formation with water temperature [Weber et al., 1975]. Over the 41 years of data, a small, yet significant correlation exists on an interannual basis between SST residuals and both calcification and extension (Figure 10). However, at the most, the influence of either calcification or extension can explain less than $10 \%$ of the residual SST values and on a monthly basis, the correlation coefficients become trivial. We extend our analysis by comparing the differences between our five fastest and slowest growing years for both corals. Variations in extension rate exhibited by these corals have no appreciable impact on mean $\delta^{18} \mathrm{O}$ or $\mathrm{Sr} / \mathrm{Ca}$, amplitude of the annual cycle, or contribute to deviations from calculated SST. In a careful study, Mendes [2004] measured intraannual extension rates at a monthly scale in a Jamaican Montastraea. The slowest extending periods were observed to occur in September with variable extension rates occurring other times during the year. The fastest extending period of time actually occurs the month preceding (August) the slow extending portion. Given this information, it seems unlikely that the pattern in the mean annual cycle of calculated water parameters (Figures $7 d$ and $7 \mathrm{e}$ ) can be produced by variable intra-annual skeletal extension rates.

[39] Kinetic effects in coral time series have largely been associated with deviations in extension rates; however, aside from growth rate parameters, kinetic effects have also been documented by a functional linkage between $\delta^{18} \mathrm{O}$ and $\delta^{13} \mathrm{C}$ positively trending toward equilibrium values [McConnaughey, 1989a, 1989b]. This relationship has been utilized by some authors to correct portions of their records where kinetic impacts are clearly evident 


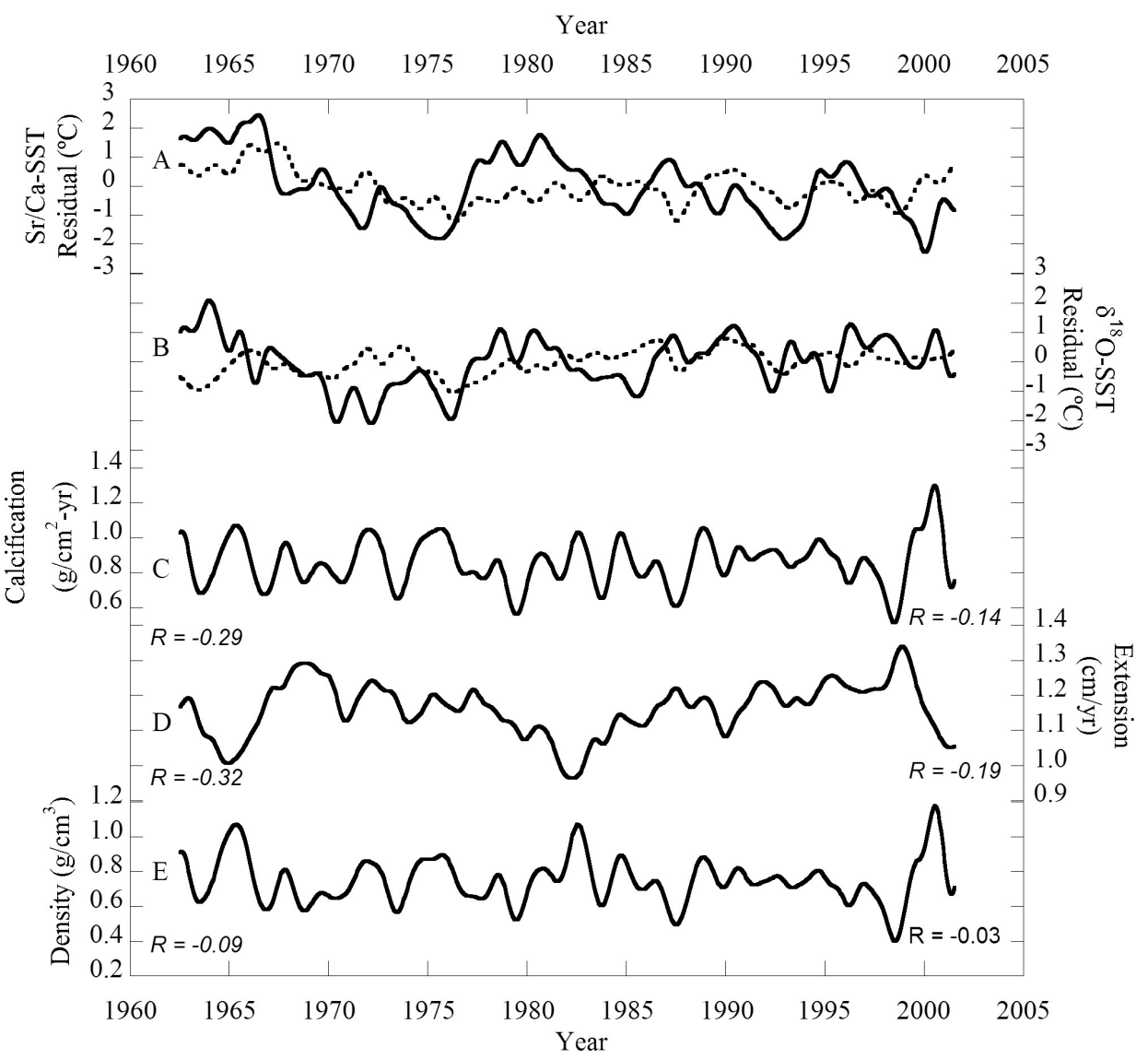

Figure 10. Variations in residual SST based on the respective calibration equations for LK1 (dashed line) and LK23 (solid line) for coral (a) $\mathrm{Sr} / \mathrm{Ca}$ and (b) $\delta^{18} \mathrm{O}$. Residuals are compared with LK23 growth parameters of (c) calcification, (d) extension, and (e) density. Extension rates for Figure 10 are derived by the $\mathrm{Sr} / \mathrm{Ca}$-time-depth relationship. All time series have been filtered to remove variability occurring at less than 2 years by use of a 25 -point convolution-type filter with a half-amplitude response at 24 months. Correlation values are given for LK23 between each individual growth parameter and both (left) $\mathrm{Sr} / \mathrm{Ca}$ SST residual and (right) $\delta^{18} \mathrm{O}-\mathrm{SST}$ residual. Residuals are calculated as the difference between instrumental SST and estimates of SST based on $\delta^{18} \mathrm{O}$ or $\mathrm{Sr} / \mathrm{Ca}$. Italicized values are at $\mathrm{p}>0.95$. LK1 growth parameters are not included as the core was unsuitable for densitometry analysis. Growth parameters for LK23 are insufficient to explain the variance in the geochemical records that remains after accounting for SST.

[Guilderson and Schrag, 1999]. The negative relationship between coral $\delta^{13} \mathrm{C}$ and $\delta^{18} \mathrm{O}$ in both Looe Key corals (slopes: $-0.14 \pm 0.02$, LK1; $-0.12 \pm 0.02$, LK23) would imply that if kinetic effects are evident in these data, then the environmental impacts must exceed those of kinetic impacts (Figure 11). The impact of variable calcification rates on the Looe $\mathrm{Key} \mathrm{Sr} / \mathrm{Ca}$ and $\delta^{18} \mathrm{O}$ records are modest to insignificant (Figure 10) and at the most can explain only $\sim 10 \%$ of the signal. Therefore, while it is tempting to attribute the synchronous changes in $\delta_{\mathrm{w}}$ and $\mathrm{Sr} / \mathrm{Ca}_{\mathrm{w}}$, or $\delta^{18} \mathrm{O}$ and $\mathrm{Sr} / \mathrm{Ca}$ to a kinetic mechanism, we are unable to arrive at this conclusion because of the lack of any mathematical consistency both over the 41 years of record and between cores. We therefore conclude that the range of both extension and calcification rates exhibited by these Looe Key corals are not sufficient to appreciably alter the geochemical signal and changes in the residual SST values must be explained by a mechanism other than growth parameters.

\subsection{Hydrographic Considerations}

[40] Variations in water properties in the Florida Keys have been tied to upwelling along the Florida Keys, tidal mixing of the waters of Florida Bay with the Straits of Florida, groundwater input, and long-term transport of water from the Gulf of Mexico to the Atlantic [Lee et al., 1994; Smith, 1994; Porter et al., 1999; Lee and Smith, 2002; Reich et al., 2002; Smith, 2002]. The isotopic composition of rainfall in south Florida is variable and ranges from 0 to $-8 \%$ versus SMOW [Swart et al., 1989], and a 2-year quasi-weekly time series of measurements of Gulf Stream waters have a mean value of $1.1 \%$ versus SMOW with an average range of $0.5 \%$ [Leder et al., 


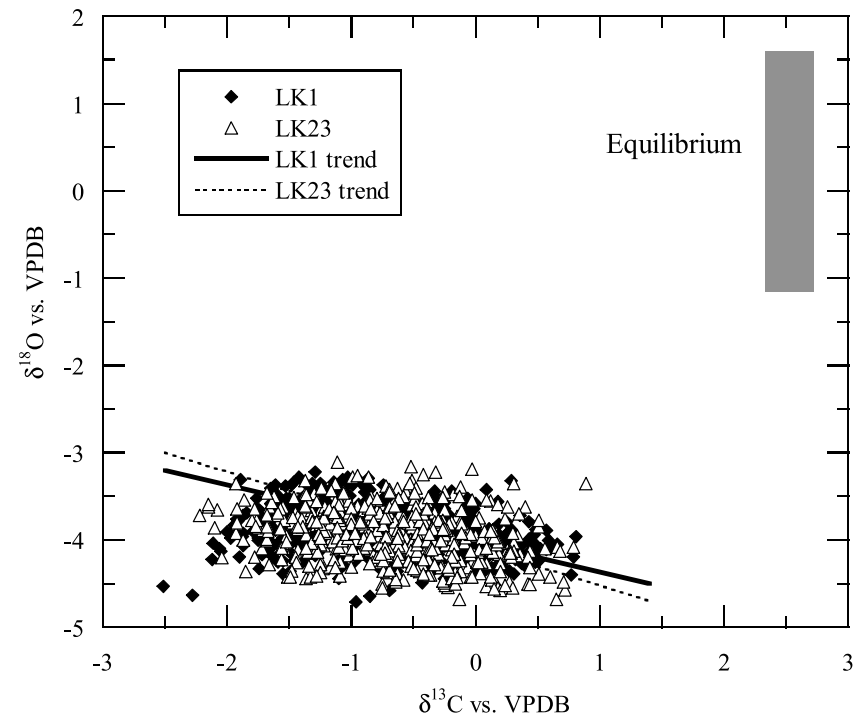

Figure 11. Scatterplot of $\delta^{13} \mathrm{C}$ and $\delta^{18} \mathrm{O}$ for both LK1 (diamonds, solid line) and LK23 (triangles, dashed line). The negative relationship between $\delta^{18} \mathrm{O}$ and $\delta^{13} \mathrm{C}$ in both corals is opposite to that observed in species where kinetic effects have a large impact on the geochemical signal. Equilibrium values (shaded gray box) are calculated using the temperature range at the reef site and mean $\delta_{\mathrm{w}}$ and DIC $\delta^{13} \mathrm{C}$ values from Leder et al. [1996] and Swart et al. [1996c].

1996]. The contribution of waters from the semienclosed basin of Florida Bay has been documented by satellite imagery to affect the Florida Keys [Roberts et al., 1982] and may affect Looe Key seasonally [Porter et al., 1999]. Low transport rates and large amounts of evaporation (i.e., increased latent heat flux) in the spring and summer [Lee and Smith, 2002; Virmani and Weisberg, 2003] can result in Florida Bay waters having $\delta^{18} \mathrm{O}$ values as high as $+3.36 \%$ versus VSMOW [Swart and Price, 2002]. An additional complication in interpreting these records over multiple seasons is that the salinity- $\delta_{\mathrm{w}}$ relationship in Florida Bay is not a straightforward mixing between isotopically light fresh water and heavier marine water (see discussion given by Swart et al. [1996b]), but is complex and can result in isotopically heavy fresh waters mixing with relatively light marine waters. In two previous coral studies in the Florida Keys, both Halley et al. [1994] and Leder et al. [1991] suggest that isotopically enriched Florida Bay waters could potentially affect summer $\delta^{18} \mathrm{O}$ water values in the reef tract resulting in a reduced $\delta^{18} \mathrm{O}$-SST amplitude, although the coral $\delta^{18} \mathrm{O}$-SST calibration equation of Leder et al. [1996] was derived over a time period where small changes in the water $\delta^{18} \mathrm{O}$ were noted. Looe Key is more susceptible to the influence of Florida Bay waters than the more northern Florida Keys locations of the Leder et al. [1991, 1996] studies lending credence to this possibility and is consistent with our calibration results.

[41] Measurements of seawater $\mathrm{Sr} / \mathrm{Ca}$ are not available at Looe Key; however, other studies in the greater Florida area report seawater $\mathrm{Sr} / \mathrm{Ca}$ values of $8.78 \mathrm{mmol} / \mathrm{mol}$ [Swarzenski et al., 2001] and $8.4 \mathrm{mmol} / \mathrm{mol}$ [Surge and Lohmann,
2002]. Highly elevated ratios of $\mathrm{Sr} / \mathrm{Ca}$, between 13.5 to $14.7 \mathrm{mmol} / \mathrm{mol}$, have been reported for submarine groundwaters discharging from the Floridian limestone aquifer system [Swarzenski et al., 2001]. The potential impact of these type of submarine discharged waters has not been assessed at Looe Key, but could potentially change the character of deeper waters $(>25 \mathrm{~m})$ that are known to upwell at this site [Lee et al., 1994; Szmant and Forrester, 1996]. Additionally, groundwater is input to Florida Bay via tidal pumping [Corbett et al., 1999] and, depending upon the level of interaction with waters from the deeper aquifer, can yield larger $\mathrm{Sr} / \mathrm{Ca}$ ratios than would be expected from open-ocean water. Conversely, $\mathrm{Sr} / \mathrm{Ca}$ ratios of fresh waters measured in three estuaries in SW Florida have greatly reduced values and show variations in $\mathrm{Sr} / \mathrm{Ca}$ with salinity, ranging from $<2-\sim 8 \mathrm{~mol} / \mathrm{mol}$ along the freshwater-to-saltwater gradient [Surge and Lohmann, 2002]. Hence, unlike open-ocean settings, large changes in water chemistry prove to be problematic for coral-climate reconstructions in this continentally influenced zone. The delivery and, hence, relative impact, of each of these sources confounds the isolation of temperature in coral $\mathrm{Sr} / \mathrm{Ca}$ records at Looe Key.

[42] The various sources of water to Looe Key can be depicted in a mixing diagram by plotting $\mathrm{Sr} / \mathrm{Ca}_{\mathrm{w}}$ versus $\delta_{\mathrm{w}}$ (Figure 12). The end-members have large ranges in both $\mathrm{Sr} / \mathrm{Ca}_{\mathrm{w}}$ and $\delta_{\mathrm{w}}$, and there is a general trend ranging from estuarine values to groundwater values with the calculated coral values falling in the middle. Synchronous changes in the timing of the data in Figures $7 \mathrm{~d}$ and $7 \mathrm{e}$ coincide with the annual cycle of precipitation, and are suggestive of a climatologically persistent link between water chemistry on the reef and rainfall. Despite this observation, on short timescales, physical processes such as spatial precipitation patterns, tidal pumping, riverine outflow, and wind-driven circulation act to "muddy the waters" by inducing variable lag times for delivery to the reef. However, when taken from a longer climatological perspective there is stronger evidence for regional interpretation of the most persistent patterns.

[43] An additional independent line of geochemical evidence that supports the conclusion that changes in water chemistry are influencing the coral geochemical record comes from the work of Purdy et al. [1989], who document amplified concentrations of ${ }^{90} \mathrm{Sr}$ and depleted concentrations of ${ }^{234,240} \mathrm{Pu}$ in annual bands of Montastraea annularis in the Florida Keys when contrasted with an open ocean site (Bermuda). Since ${ }^{90} \mathrm{Sr}$ has no natural source and is only produced as a product of nuclear weapons testing, the only mechanism that could concentrate large quantities of ${ }^{90} \mathrm{Sr}$ beyond levels expected from direct fallout alone must come from coastal run-off sources. Moreover, a coastal run-off explanation is further substantiated by depleted concentrations of ${ }^{234,240} \mathrm{Pu}$ during the same period of coral growth, which is consistent with scavenging by particles in coastal waters.

\section{Conclusions}

[44] We compared monthly resolved geochemical variations of $\mathrm{Sr} / \mathrm{Ca}, \delta^{18} \mathrm{O}$, and $\delta^{13} \mathrm{C}$ in two separate heads of 


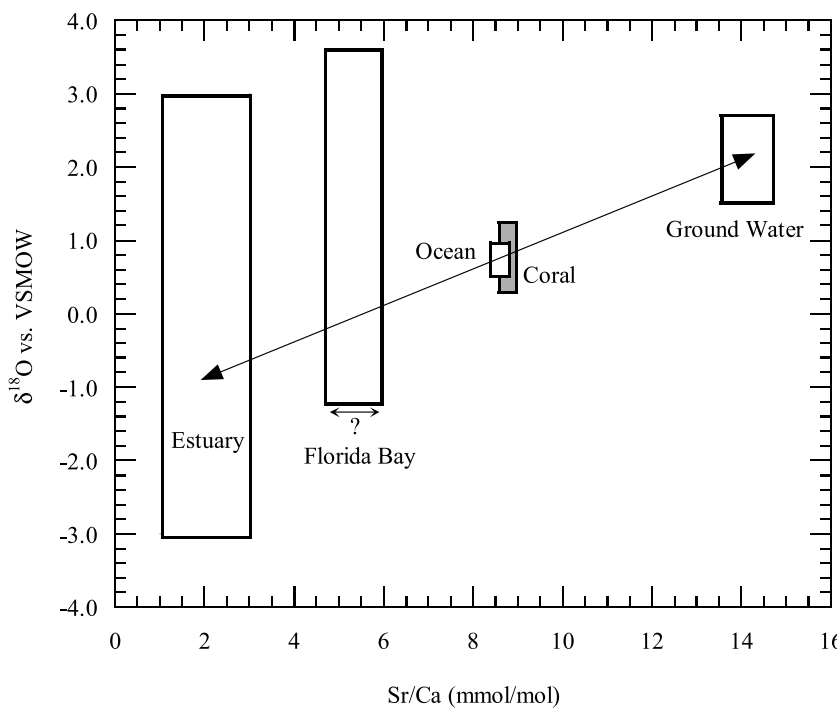

Figure 12. Mixing diagram comparing literature $\mathrm{Sr} / \mathrm{Ca}_{\mathrm{w}}$ and $\delta_{\mathrm{w}}$ values and coral-based seawater values calculated from equations (4) and (7). Florida Bay $\mathrm{Sr} / \mathrm{Ca}_{\mathrm{w}}$ values are assumed to be a mean value between estuary and ocean values. Literature values are derived from Surge and Lohmann [2002], Swart and Price [2002], Swarzenski et al. [2001], Leder et al. [1996], and Böhlke et al. [1999]. Coral-derived values of $\mathrm{Sr} / \mathrm{Ca}_{\mathrm{w}}$ and $\delta_{\mathrm{w}}$ are indicated by the shaded box and overlap typical ocean values.

Montastraea faveolata from Looe Key Reef, Florida, over a 41-year interval to assess how well two corals from the same reef record sea surface environmental conditions. The stable isotope time series replicate well between the two coral heads as is evidenced by their indistinguishable mean values. In contrast, the mean $\mathrm{Sr} / \mathrm{Ca}$ values of the two corals differ significantly and indicate that nonenvironmental factors are influencing the coral $\mathrm{Sr} / \mathrm{Ca}$ records at Looe Key.

[45] Synchronous anomalies in coral $\mathrm{Sr} / \mathrm{Ca}$ and $\delta^{18} \mathrm{O}$ are independent of changes in SST. Direct regression of $\delta^{18} \mathrm{O}$ and $\mathrm{Sr} / \mathrm{Ca}$ onto SST yields equations that are significantly different from previously published equations for Montastraea. Variations in growth parameters or kinetic impacts are not sufficient to explain this difference in calibrations, which is most likely due to variations in water chemistry not accounted for in the regression analysis. Similar to the $\delta^{18} \mathrm{O}-\delta_{\mathrm{w}}-\mathrm{SST}$ relationship, we have isolated $\mathrm{Sr} / \mathrm{Ca}$ variations in water chemistry over the length of the instrumental record by solving a modified $\mathrm{Sr} / \mathrm{Ca}_{\text {coral }}-\mathrm{Sr} / \mathrm{Ca}_{\mathrm{w}}-\mathrm{SST}$ relationship which includes an additional variable to account for the water parameters. Our results highlight the confounding impact of variable water chemistry on the use of paired $\mathrm{Sr} / \mathrm{Ca}$ and $\delta^{18} \mathrm{O}$ in Montastraea paleothermometry at this site.

[46] Future work on Atlantic Montastraea should include the generation of additional geochemical records, multiple decades in length, complemented whenever possible by seawater chemistry determinations so that a more complete assessment of the climate utility of Montastraea can be made. Also, additional studies of replication involving more specimens will allow for greater confidence in interpretation of paleoclimate records derived from Montastraea corals.

[47] Acknowledgments. The authors would like to gratefully acknowledge the helpful comments, suggestions, and contributions from Ethan Goddard, Harold Hudson, Hali Kilbourne, Gary Mitchum, Johan Schijf, Dick Poore, Gene Shinn, Mark Eakin, Vembu Subramanian, Peter Swart, Charles Holmes, and Chris Reich. Thoughtful and helpful suggestions were made by Chris Moses and an anonymous reviewer. Data were provided by the SERC-FIU Water Quality Monitoring Network, which is supported by SFWMD/SERC Cooperative Agreements C-10244 and C-13178 as well as EPA Agreement X994621-94-0 (available at http:// serc.fiu.edu/wqmnetwork/FKNMS-CD/index.htm). This project was supported by grants from NOAA Office of Global Programs, NOAA Coastal Ocean Program Award NA160A1443 to NCRI, the St. Petersburg Progress Endowed Fellowship in Coastal Science, and the Gulf Oceanic Charitable Trust.

\section{References}

Alibert, C., and M. T. McCulloch (1997), Strontium/calcium ratios in modern Porites corals from the Great Barrier Reef as a proxy for sea surface temperature: Calibration of the thermometer and monitoring of ENSO, Paleoceanography, 12, 345-363.

Alibert, C., L. Kinsley, S. J. Fallon, M. T. McCulloch, R. Berkelmans, and F. McAllister (2003), Source of trace element variability in Great Barrier Reef corals affected by the Burdekin flood plumes, Geochim. Cosmochim. Acta, 67, 231-246.

Allison, N., and A. A. Finch (2004), Highresolution $\mathrm{Sr} / \mathrm{Ca}$ records in modern Porites lobata corals: Effects of skeletal extension rate and architecture, Geochem. Geophys. Geosyst., 5, Q05001, doi:10.1029/2004GC000696.

Bernstein, R. E., R. H. Byrne, P. R. Betzer, and A. M. Greco (1992), Morphologies and transformations of celestite in seawater: The role of acantharians in strontium and barium geochemistry, Geochim. Cosmochim. Acta, 56, 3273-3279.

Böhlke, J. K., L. N. Plummer, E. Busenberg, T. B. Coplen, E. A. Shinn, and P. Schlosser
(1999), Origins, residence times, and nutrient sources of marine ground water beneath the Florida Keys and nearby offshore areas, paper presented at South Florida Restoration Science Forum, U.S. Geol. Surv., Boca Raton, Fla.

Brass, G. W. (1980), Trace elements in acantharian skeletons, Limnol. Oceanogr., 25, 146149.

Buster, N., and C. Holmes (2006), Magnesium content within the skeletal architecture of the coral Montastraea faveolata: Locations of brucite and implications to fine-scale data fluctuations, Coral Reefs, in press.

Cardinal, D., B. Hamelin, E. Bard, and J. Patzold (2001), $\mathrm{Sr} / \mathrm{Ca}, \mathrm{U} / \mathrm{Ca}$ and $\delta^{18} \mathrm{O}$ records in recent massive corals from Bermuda: Relationships with sea surface temperature, Chem. Geol., $176,213-233$

Cobb, K. M., C. D. Charles, H. Cheng, and R. L. Edwards (2003), El Niño/Southern Oscillation and tropical Pacific climate during the last millennium, Nature, 424, 271-276.

Cohen, A. L., and S. Hart (2004), Deglacial sea surface temperatures of the western tropical
Pacific: A new look at old coral, Paleoceanography, 19, PA4031, doi:10.1029/ 2004PA001084.

Cohen, A. L., G. D. Layne, S. R. Hart, and P. S. Lobel (2001), Kinetic control of skeletal $\mathrm{Sr} / \mathrm{Ca}$ in a symbiotic coral: Implications for the paleotemperature proxy, Paleoceanography, 16 , 20-26

Cole, J. E., R. G. Fairbanks, and G. T. Shen (1993), Recent variability in the Southern Oscillation: Isotopic results from a Tarawa atoll coral, Science, 260, 1790-1793.

Corbett, D. R., J. Chanton, W. Burnett, K. Dillon, C. Rutkowski, and J. W. Fourqurean (1999), Patterns of groundwater discharge into Florida Bay, Limnol. Oceanogr., 44, $1045-$ 1055

Correge, T., M. K. Gagan, J. W. Beck, G. S Burr, G. Cabioch, and F. Le Cornec (2004), Interdecadal variation in the extent of South Pacific tropical waters during the Younger Dryas event, Nature, 428, 927-929.

Crowley, T. J., T. M. Quinn, and W. T. Hyde (1999), Validation of coral temperature calibrations, Paleoceanography, 14, 605-615. 
Davis, J. C. (2002), Statistics and Data Analysis in Geology, 3rd ed., John Wiley, Hoboken, N. J.

de Deckker, P. (2004), On the celestite-secreting Acantharia and their effect on seawater strontium to calcium ratios, Hydrobiologia, 517, 1 13

de Villiers, S., G. T. Shen, and B. K. Nelson (1994), The Sr/Ca-temperature relationship in coralline aragonite-Influence of variability in $(\mathrm{Sr} / \mathrm{Ca})_{\text {seawater }}$ and skeletal growth parameters, Geochim. Cosmochim. Acta, 58, 197-208.

de Villiers, S., B. K. Nelson, and A. R. Chivas (1995), Biological controls on coral $\mathrm{Sr} / \mathrm{Ca}$ and $\delta^{18} \mathrm{O}$ reconstructions of sea surface temperatures, Science, 269, 1247-1249.

Druffel, E. M. (1983), Long-term variability of temperature and C-14 in the Gulf-StreamOceanographic implications, Radiocarbon, $25,449-458$.

Druffel, E. M., and H. E. Suess (1983), On the radiocarbon record in banded corals: Exchange parameters and net transport of ${ }^{14} \mathrm{CO}_{2}$ between atmosphere and surface ocean, J. Geophys. Res., 88, 1271-1280.

Fairbanks, R. G., and R. E. Dodge (1979), Annual periodicity of the ${ }^{18} \mathrm{O} /{ }^{16} \mathrm{O}$ and ${ }^{13} \mathrm{C} /{ }^{12} \mathrm{C}$ ratios in the coral Montastraea annularis, Geochim. Cosmochim. Acta, 43, 1009-1020.

Fairbanks, R. G., C. D. Charles, and J. D. Wright (1992), Origin of global meltwater pulses, in Radiocarbon After Four Decades: An Interdisciplinary Perspective, edited by R. E. Taylor et al., pp. 473-500, Springer, New York.

Felis, T., J. Patzold, and Y. Loya (2003), Mean oxygen-isotope signatures in Porites spp. corals: Inter-colony variability and correction for extension-rate effects, Coral Reefs, 22, 328336.

Gagan, M. K., L. K. Ayliffe, D. Hopley, J. A. Cali, G. E. Mortimer, J. Chappell, M. T. McCulloch, and M. J. Head (1998), Temperature and surface-ocean water balance of the mid-Holocene tropical western Pacific, Science, 279, 1014-1018

Gagan, M. K., L. K. Ayliffe, J. W. Beck, J. E. Cole, E. R. M. Druffel, R. B. Dunbar, and D. P. Schrag (2000), New views of tropical paleoclimates from corals, Quat. Sci. Rev., $19,45-64$.

Gischler, E., and W. Oschmann (2005), Historical climate variation in Belize (Central America) as recorded in scleractinian coral skeletons, Palaios, 20, 159-174.

Goodkin, N. F., K. A. Hughen, A. L. Cohen, and S. R. Smith (2005), Record of Little Ice Age sea surface temperatures at Bermuda using a growth-dependent calibration of coral $\mathrm{Sr} / \mathrm{Ca}$, Paleoceanography, 20, PA4016, doi:10.1029/ 2005PA001140

Guilderson, T. P., and D. P. Schrag (1999), Reliability of coral isotope records from the western Pacific warm pool: A comparison using age-optimized records, Paleoceanography, 14, 457-464.

Guilderson, T. P., J. E. Cole, and J. R. Southon (2005), Pre-bomb $\Delta{ }^{14} \mathrm{C}$ variability and the Suess effect in Cariaco Basin surface waters as recorded in hermatypic corals, Radiocarbon, 47, 57-65.

Halley, R. B., P. K. Swart, R. E. Dodge, and J. H. Hudson (1994), Decade-scale trend in sea water salinity revealed through $\delta^{18} \mathrm{O}$ analysis of Montastraea annularis annual growth bands, Bull. Mar. Sci., 54, 670-678.

Highsmith, R. C. (1979), Coral growth rates and environmental control of density banding, J. Exp. Mar. Biol. Ecol., 37, 105-125.
Hudson, J. H., E. A. Shinn, R. B. Halley, and B. Lidz (1976), Sclerochronology: A tool for interpreting past environments, Geology, 4, $361-364$.

Kilbourne, K. H., T. M. Quinn, F. Taylor, T. Delcroix, and Y. Gouriou (2004), El NiñoSouthern Oscillation-related salinity variations recorded in the skeletal geochemistry of a Porites coral from Espiritu Santo, Vanuatu, Paleoceanography, 19, PA4002, doi:10.1029/ 2004PA001033.

Kinsman, D. J. J., and H. D. Holland (1969), The co-precipitation of $\mathrm{Sr}^{2+}$ with aragonite between $16^{\circ}$ and $96^{\circ} \mathrm{C}$, Geochim. Cosmochim. Acta, 33 , $1-17$.

Knowlton, N., E. Weil, L. A. Weigt, and H. M. Guzman (1992), Sibling species in Montastraea annularis, coral bleaching, and the coral climate record, Science, 255, 330-333.

Kortzinger, A., P. D. Quay, and R. E. Sonnerup (2003), Relationship between anthropogenic $\mathrm{CO}_{2}$ and the ${ }^{13} \mathrm{C}$ Suess effect in the North Atlantic Ocean, Global Biogeochem. Cycles, 17(1), 1005, doi:10.1029/2001GB001427.

Land, L. S., J. C. Lang, and D. J. Barnes (1975), Extension rate: Primary control on isotopic composition of West Indian (Jamaican) scleractinian reef coral skeletons, Mar. Biol., 33, 221-233.

Le Bec, N., A. Juillet-Leclerc, T. Correge, D. Blamart, and T. Delcroix (2000), A coral $\delta^{18} \mathrm{O}$ record of ENSO driven sea surface salinity variability in Fiji (south-western tropical Pacific), Geophys. Res. Lett., 27, 3897-3900.

Leder, J. J., A. M. Szmant, and P. K. Swart (1991), The effect of prolonged bleaching on skeletal banding and stable isotopic composition in Montastraea annularis: Preliminary observations, Coral Reefs, 10, 19-27.

Leder, J. J., P. K. Swart, A. M. Szmant, and R. E. Dodge (1996), The origin of variations in the isotopic record of scleractinian corals: I. Oxygen, Geochim. Cosmochim. Acta, 60, $2857-$ 2870

Lee, T. N., and N. Smith (2002), Volume transport variability through the Florida Keys tidal channels, Cont. Shelf Res., 22, 1361-1377.

Lee, T. N., M. E. Clarke, E. Williams, A. F. Szmant, and T. Berger (1994), Evolution of the Tortugas Gyre and its influence on recruitment in the Florida Keys, Bull. Mar. Sci., 54, $621-646$.

Linsley, B. K., R. B. Dunbar, G. M. Wellington, and D. A. Mucciarone (1994), A coral-based reconstruction of Intertropical Convergence Zone variability over Central America since 1707, J. Geophys. Res., 99, 9977-9994.

Linsley, B. K., R. G. Messier, and R. B. Dunbar (1999), Assessing between-colony oxygen isotope variability in the coral Porites lobata at Clipperton Atoll, Coral Reefs, 18, 13-27.

Marshall, J. F., and M. T. McCulloch (2002), An assessment of the $\mathrm{Sr} / \mathrm{Ca}$ ratio in shallow water hermatypic corals as a proxy for sea surface temperature, Geochim. Cosmochim. Acta, 66, $3263-3280$.

McConnaughey, T. (1989a), ${ }^{13} \mathrm{C}$ and ${ }^{18} \mathrm{O}$ isotopic disequilibrium in biological carbonates: I. In vitro simulation of kinetic isotope effects, Geochim. Cosmochim. Acta, 53, 163-171.

McConnaughey, T. $(1989 \mathrm{~b}),{ }^{13} \mathrm{C}$ and ${ }^{18} \mathrm{O}$ isotopic disequilibrium in biological carbonates: I. Patterns, Geochim. Cosmochim. Acta, 53, $151-162$.

McCulloch, M. T., M. K. Gagan, G. E. Mortimer, A. R. Chivas, and P. J. Isdale (1994), A highresolution $\mathrm{Sr} / \mathrm{Ca}$ and $\delta^{18} \mathrm{O}$ coral record from the Great Barrier Reef, Australia, and the
1982-1983 El Niño, Geochim. Cosmochim. Acta, 58, 2747-2754

Mendes, J. (2004), Timing of skeletal band formation in Montastraea annularis: Relationship to environmental and endogenous factors, Bull. Mar. Sci., 75, 423-437.

Mitsuguchi, T., E. Matsumoto, and T. Uchida (2003), $\mathrm{Mg} / \mathrm{Ca}$ and $\mathrm{Sr} / \mathrm{Ca}$ ratios of Porites coral skeleton: Evaluation of the effect of skeletal growth rate, Coral Reefs, 22, 381-388.

Paillard, D., L. Labeyrie, and P. Yiou (1996), Macintosh Program Performs Time-Series Analysis, Eos Trans. AGU, 77(39), 379.

Pilson, M. (1998), An Introduction to the Chemistry of the Sea, Prentice-Hall, Upper Saddle River, N. J.

Porter, J. W., S. K. Lewis, and K. G. Porter (1999), The effect of multiple stressors on the Florida Keys coral reef ecosystem: A landscape hypothesis and a physiological test, Limnol. Oceanogr., 44, 941-949.

Purdy, C. B., E. R. M. Druffel, and H. D. Livingston (1989), Anomalous levels of ${ }^{90} \mathrm{Sr}$ and ${ }^{239,240} \mathrm{Pu}$ in Florida corals: Evidence of coastal processes, Geochim. Cosmochim. Acta, 53 , $1401-1410$.

Quinn, T. M., F. W. Taylor, T. J. Crowley, and S. M. Link (1996), Evaluation of sampling resolution in coral stable isotope records: A case study using records from New Caledonia and Tarawa, Paleoceanography, 11, 529-542.

Rayner, N. A., D. E. Parker, E. B. Horton, C. K. Folland, L. V. Alexander, D. P. Rowell, E. C. Kent, and A. Kaplan (2003), Global analyses of sea surface temperature, sea ice, and night marine air temperature since the late nineteenth century, J. Geophys. Res., 108(D14), 4407, doi:10.1029/2002JD002670

Reich, C. D., E. A. Shinn, T. D. Hickey, and A. B. Tihansky (2002), Tidal and meteorological influences on shallow marine groundwater flow in the upper Florida Keys, in The Everglades, Florida Bay, and Coral Reefs of the Florida Keys: An Ecosystem Sourcebook, edited by J. W. Porter and K. G. Porter, pp. 659 676, CRC Press, Boca Raton, Fla.

Reuer, M. K., E. A. Boyle, and J. E. Cole (2003) A mid-twentieth century reduction in tropical upwelling inferred from coralline trace element proxies, Earth Planet. Sci. Lett., 210, $437-$ 452.

Roberts, H. H., L. J. Rouse, N. D. Walker, and J. H. Hudson (1982), Cold-water stress in Florida Bay and northern Bahamas: A product of winter cold-air outbreaks, J. Sediment. Petrol. $52,145-156$

Schrag, D. P. (1999), Rapid analysis of high-precision $\mathrm{Sr} / \mathrm{Ca}$ ratios in corals and other marine carbonates, Paleoceanography, 14, 97-102.

Shen, C. C., T. Lee, C. Y. Chen, C. H. Wang, C. F. Dai, and L. A. Li (1996), The calibration of $D[\mathrm{Sr} / \mathrm{Ca}]$ versus sea surface temperature relationship for Porites corals, Geochim. Cosmochim. Acta, 60, 3849-3858.

Smith, N. P. (1994), Long-term Gulf-to-Atlantic transport through tidal channels in the Florida Keys, Bull. Mar. Sci., 54, 602-609.

Smith, N. P. (2002), Tidal, low-frequency and long-term mean transport through two channels in the Florida Keys, Cont. Shelf Res. $22,1643-1650$.

Smith, S. V., R. W. Buddemeier, R. C. Redalje, and J. E. Houck (1979), Strontium-calcium thermometry in coral skeletons, Science, 204, 404-407.

Stephans, C. L., T. M. Quinn, F. W. Taylor, and T. Corrège (2004), Assessing the reproducibility of coral-based climate records, Geophys. 
Res. Lett. 31, L18210, doi:10.1029/ 2004GL020343.

Sun, Y., M. Sun, T. Lee, and B. Nie (2005), Influence of seawater $\mathrm{Sr}$ content on coral $\mathrm{Sr} / \mathrm{Ca}$ and Sr thermometry, Coral Reefs, 24, 23-29.

Surge, D. M., and K. C. Lohmann (2002), Temporal and spatial differences in salinity and water chemistry in SW Florida estuaries: Effects of human-impacted watersheds, Estuaries, 25, 393-408

Swart, P. K., and K. Price (2002), Origin of salinity variations in Florida Bay, Limnol. Oceanogr., 47, 1234-1241

Swart, P. K., L. Sternberg, R. Steinen, and S. A. Harrison (1989), Controls on the oxygen and hydrogen isotopic composition of the waters of Florida Bay, USA, Chem. Geol., 79, 113-123.

Swart, P. K., R. E. Dodge, and H. J. Hudson (1996a), A 240-year stable oxygen and carbon isotopic record in a coral from south Florida: Implications for the prediction of precipitation in southern Florida, Palaios, 11, 362-375.

Swart, P. K., G. F. Healy, R. E. Dodge, P. Kramer, J. H. Hudson, R. B. Halley, and M. B. Robblee (1996b), The stable oxygen and carbon isotopic record from a coral growing in Florida Bay: A 160 year record of climatic and anthropogenic influence, Palaeogeogr. Palaeoclimatol. Palaeoecol., 123, 219-237.

Swart, P. K., J. J. Leder, A. M. Szmant, and R. E. Dodge (1996c), The origin of variations in the isotopic record of scleractinian corals: II. Carbon, Geochim. Cosmochim. Acta, 60, 2871-2885.
Swart, P. K., G. Healy, L. Greer, M. Lutz, A. Saied D. Anderegg, R. E. Dodge, and D. Rudnick (1999), The use of proxy chemical records in coral skeletons to ascertain past environmental conditions in Florida Bay, Estuaries, 2+2, 384-397.

Swart, P. K., H. Elderfield, and M. J. Greaves (2002), A high-resolution calibration of $\mathrm{Sr} / \mathrm{Ca}$ thermometry using the Caribbean coral Montastraea annularis, Geochem. Geophys. Geosyst., 3(11), 8402 , doi:10.1029 2002GC000306.

Swarzenski, P. W., C. D. Reich, R. M. Spechler, J. L. Kindinger, and W. S. Moore (2001), Using multiple geochemical tracers to characterize the hydrogeology of the submarine spring off Crescent Beach, Florida, Chem. Geol., 179, 187-202.

Szmant, A. M., and A. Forrester (1996), Water column and sediment nitrogen and phosphorus distribution patterns in the Florida Keys, USA, Coral Reefs, 15, 21-41.

Virmani, J. I., and R. H. Weisberg (2003), Features of the observed annual ocean-atmosphere flux variability on the west Florida shelf, J. Clim., 16, 734-745.

Watanabe, T., M. Minagawa, T. Oba, and A. Winter (2001a), Pretreatment of coral aragonite for $\mathrm{Mg}$ and $\mathrm{Sr}$ analysis: Implications for coral thermometers, Geochem. J., 35, 265-269.

Watanabe, T., A. Winter, and T. Oba (2001b), Seasonal changes in sea surface temperature and salinity during the Little Ice Age in the Caribbean
Sea deduced from $\mathrm{Mg} / \mathrm{Ca}$ and ${ }^{18} \mathrm{O} /{ }^{16} \mathrm{O}$ ratios in corals, Mar. Geol., 173, 21-35.

Watanabe, T., A. Winter, T. Oba, R. Anzai, and H. Ishioroshi (2002), Evaluation of the fidelity of isotope records as an environmental proxy in the coral Montastraea, Coral Reefs, 21, $169-178$.

Weber, J. N. (1973), Incorporation of strontium into reef coral skeletal carbonate, Geochim. Cosmochim. Acta, 37, 2173-2190.

Weber, J. N., and P. M. Woodhead (1970), Carbon and oxygen isotope fractionation in skeletal carbonate of reef-building corals, Chem Geol., 6, 93-117.

Weber, J. N., P. Deines, E. W. White, and P. H. Weber (1975), Seasonal high and low-density bands in reef coral skeletons, Nature, 255 , 697-698.

R. B. Halley, U.S. Geological Survey, 600 4th Street South, St. Petersburg, FL 33701, USA

K. P. Helmle, Nova Southeastern University Oceanographic Center, National Coral Reef Institute, 8000 North Ocean Drive, Dania Beach, FL 33004, USA.

T. M. Quinn and J. M. Smith, College of Marine Science, University of South Florida, 140 Seventh Avenue South, St. Petersburg, FL 33701, USA. (jsmith@marine.usf.edu) 